\title{
Sediment and Radionuclide Transport in Rivers; Field Sampling Program, Cattaraugus and Buttermilk Creeks, New York
}

\section{Annual Progress Report \\ October 1978 - September 1979}

Prepared by Y. Onishi, W. H. Walters, R. M. Ecker

Pacific Northwest Laboratory

Operated by

Battelle Memorial Institute

Prepared for

U.S. Nuclear Regulatory

Commission 


\section{NOTICE}

This report was prepared as an account of work sponsored by an agency of the United States Government. Neither the United States Government nor any agency thereof, or any of their employees, makes any warranty, expressed or implied, or assumes any legal liability or responsibility for any third party's use, or the results of such use, of any information, apparatus product or process disclosed in this report, or represents that its use by such third party would not infringe privately owned rights.

\section{Available from}

GPO Sales Program

Division of Technical Information and Document Control

U. S. Nuclear Regulatory Commission

Washington, D. C. 20555

Printed copy price: $\$ 3.75$

and

National Technical Information Service

Springfield, Virginia 22161 


\section{Sediment and Radionuclide Transport in Rivers; Field Sampling Program, Cattaraugus and Buttermilk Creeks, New York}

\section{Annual Progress Report}

October 1978 - September 1979

Manuscript Completed: September 1980

Date Published: January 1981

Prepared by

Y. Onishi, W. H. Walters, R. M. Ecker

Pacific Northwest Laboratory

Richland, WA 99352

\section{Prepared for}

Division of Safeguards, Fuel Cycle and Environmental Research

Office of Nuclear Regulatory Research

U.S. Nuclear Regulatory Commission

Washington, D.C. 20555

NRC FIN No. B2275 



\section{ABSTRACT}

This report describes FY-1979 analys is results on flow, sediment and radionuclide data collected in Cattaraugus, Buttermilk and Franks Creek, New York. The objective of the study is to investigate the radionuclide transport in these streams as a part of a continuing program to provide data required for application and verification of the Sediment and Radionuclide Transport Model (SERATRA). Radiological analyses were performed on sand, silt and clay size fractions of suspended and bed sediment, as well as for dissolved radionuclides. These include gamma-ray emitters plus ${ }^{90} \mathrm{Sr},{ }^{238} \mathrm{Pu},{ }^{239-240} \mathrm{Pu}$, ${ }^{241} \mathrm{Am},{ }^{244} \mathrm{Cm}$ and ${ }^{3} \mathrm{H}$. Among radionuclides analyzed to date, a principal radionuclide found in the study area is ${ }^{137} \mathrm{Cs}$. Distributions of ${ }^{137} \mathrm{Cs}$ associated with suspended and bed sediments have sharp peaks at the mouth of the Franks Creek, revealing the contribution of ${ }^{137} \mathrm{Cs}$ from the NFS site. Concentration of ${ }^{137} \mathrm{Cs}$ associated with a clay size fraction of suspended and bed sediments at the mouth of Franks Creek were $32.5 \pm 1.5$ and $134.0 \pm 0.90 \mathrm{pCi} / \mathrm{g}$, respectively. Cesium-134 and cobalt-60 associated with the bed sediment also have higher peaks at the mouth of Franks Creek. However, dissolved and particulate concentrations of other radionuclides analyzed under this study were generally very low and there is no clear evidence to indicate that these radionculides detected in this study area originated from the Nuclear Fuel Service site. 


\section{SUMMARY}

This report describes FY-1979 results of the field sampling program performed on the Cattaragus, Buttermilk and Franks Creeks near the West Valley burial site (the Western New York Nuclear Service Center operated by the Nuclear Fuel Service Inc.), New York. The objective of this study is to investigate the radionuclide transport in these streams as a part of a continuing program to provide data required for application and verification of the Pacific Northwest Laboratory's (PNL) sediment and radionuclide transport model, SERATRA.

The program is divided into three phases: Phase 1 , medium-flow condition; Phase 2, low-flow condition; and Phase 3, high flow condition. Under each of these three conditions, flow, sediment and radionuclide data in Cattaraugus, Buttermilk and Franks Creeks were collected and analyzed. Franks Creek receives runoff from the waste site of the Nuclear Fuel Service (NFS) Inc, and is a tributary of Buttermilk Creek which flows into Cattaraugus Creek. Cattaraugus Creek discharges into Lake Erie. Field data collection for Phases 1, 2 and 3 were performed during November 30 - December 5, 1977; September 20-27, 1978; and April 26-29, 1979, respectively.

Radiological analyses were performed on sand, silt and clay size fractions of suspended and bed sediment samples, as well as on filters, aluminum oxide and resin beds from filtering water samples. Radiological analyses were per-

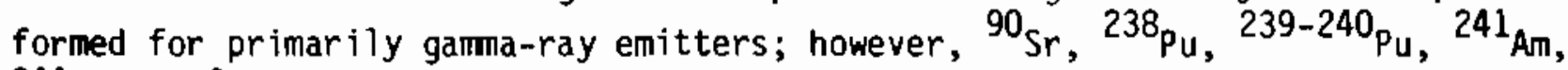
${ }^{244} \mathrm{Cm}$ and ${ }^{3} \mathrm{H}$ were also analyzed for selected samples.

Among the radionuclides analyzed under Phase 2 , a dominant radionuclide found in the study area is ${ }^{137} \mathrm{Cs}$. Distributions of ${ }^{137} \mathrm{Cs}$ associated with suspended and bed sediments have sharp peaks at the mouth of Franks Creek, revealing the contributions of ${ }^{137}$ Cs from the NFS into the Franks-ButtermilkCattaraugus Creek System. The maximum levels of ${ }^{137} \mathrm{Cs}$ associated with suspended and bed sediments at the mouth of Franks Creek were $32.5 \pm 1.5$ and $134.0 \pm 0.90 \mathrm{pCi} / \mathrm{g}$ in a clay fraction of sediment. Gamma activity in water was very low for Phase 1 samples. Cesium-137 levels in water at the mouth 
of Franks Creek vary from $0.194 \pm 0.02$ to $0.12 \pm 0.10 \mathrm{pCi} / \mathrm{l}$ and were not high enough to clearly distinguish them from background levels.

Cesium-134 and cobalt-60 remaining in the stream bed sediments also have their highest concentrations at the mouth of Franks Creek. However, levels of these two radionuclides adsorbed by suspended sediment and those in dissolved forms were near background or below detection levels.

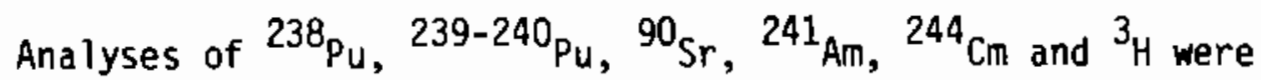

performed for Phase 1 samples. Dissolved and particulate concentrations of these radionuclides were generally very low and there is no clear evidence to indicate that these radionuclides detected in the study area originated from the NFS site.

During the Phase 3 field data collection, stream flow was monitored at nine temporary gaging stations and suspended sediment samples collected at seven of the locations. The gaging stations were established to provide detailed water and suspended sediment monitoring for a reach of Cattaraugas Creek from Bigelow Bridge (41.3 miles above Lake Erie) to a point about $900 \mathrm{ft}$ below Frye Bridge ( 32.7 miles above Lake Erie). Five of the gages were located on tributary streams of the Cattaraugas Creek system and four on Cattaraugas Creek. The streamflow records provide input data for the hydraulic modeling of the creek system. The hydraulic modeling results will be used as input to SERATRA along with the suspended sediment data for the simulation of the water, sediment, and radionuclide movement. 


\section{ACKNOWLEDGMENTS}

This report summarizes the results of research conducted by the Battelle Memorial Institute's Pacific Northwest Laboratory for the U.S. Nuclear Regulatory Commission on Cattaraugus and Buttermilk Creeks, New York, from October 1, 1978 to September 30, 1979. In addition to the authors of this report, significant contributions were made by R. G. Parkhurst for his field and laboratory expertise; S. M. Brown and E. M. Arnold for the ir efforts in the field; and, S. J. Phillips, and D. D. Hostetler for their scuba diving capabilities. The authors also wish to acknowledge the guidance and assistance provided by Dr. Phillip R. Reed of the U.S. Nuclear Regulatory Commission (NRC), Dr. R. H. Fakundiny, R. H. Fickies, and S. A. Mollelo of the New York State Geological Survey.

Support work for the project was performed uner a separate subcontract to Drs. William R. Sche1l and Thomas Sibley of the University of Washington, Laboratory of Radiation Ecology for radiological analyses. 


\section{CONTENTS}

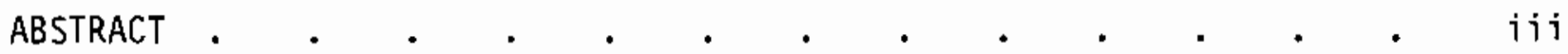

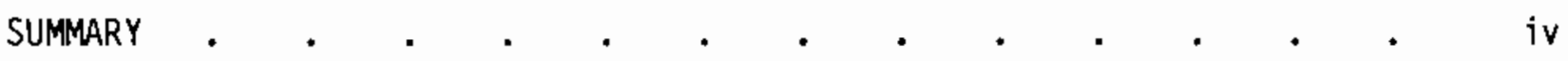

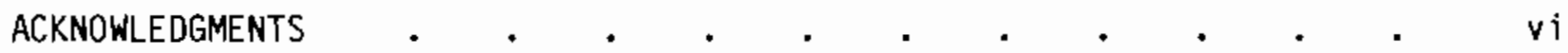

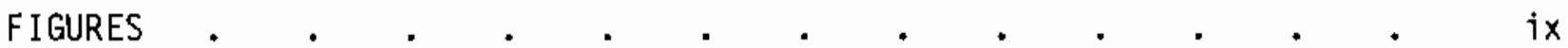

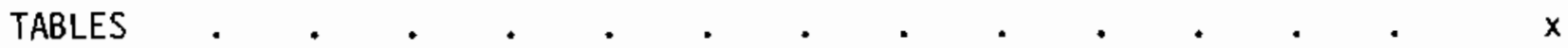

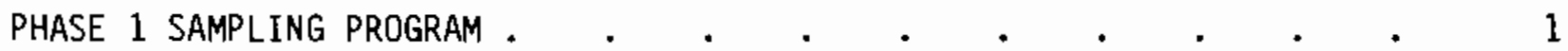

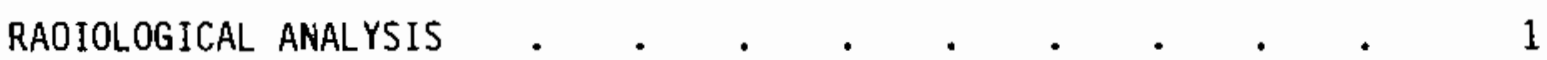

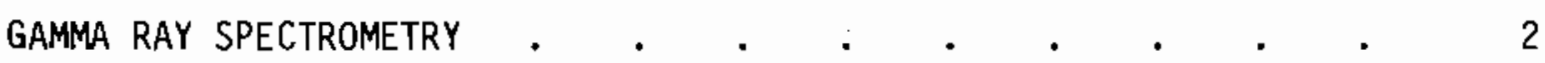

Gamma Activity Associated With Water . $\quad$ • . . $\quad 2$

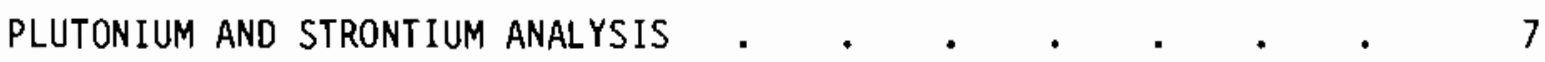

Plutonium and Strontium in Suspended Sediment . . . 7

PJutonium and Strontium in Bed Sediment . . . . . 10

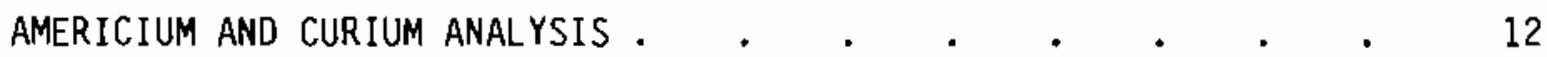

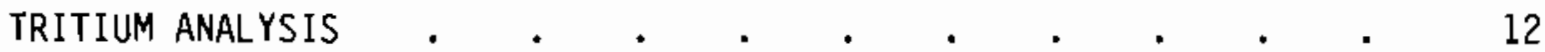

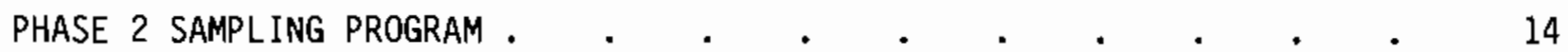

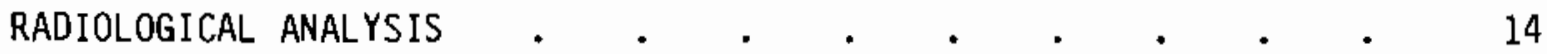

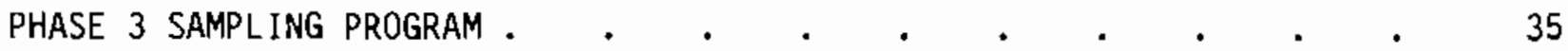

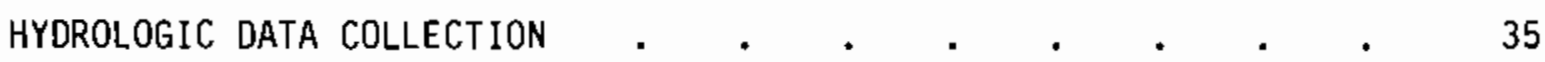

Purpose of Monitoring Effort . . . . . . . 35

CATTARAUGAS CREEK WATERSHED . : . . . . . . . 36

Location . . . . . . . . . . . . . 36

Geomorphology . . . . . . . . . . . . 36

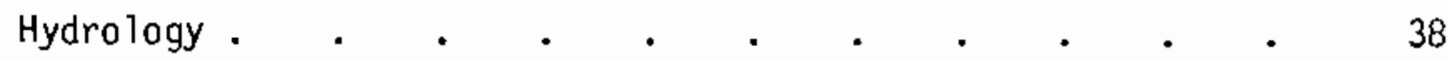

HYDROLOGIC DATA COLLECTION $\quad$. . . . . . . . . . . . . 39

Steam Gage Network . . . . . . . . . . . . . 41 


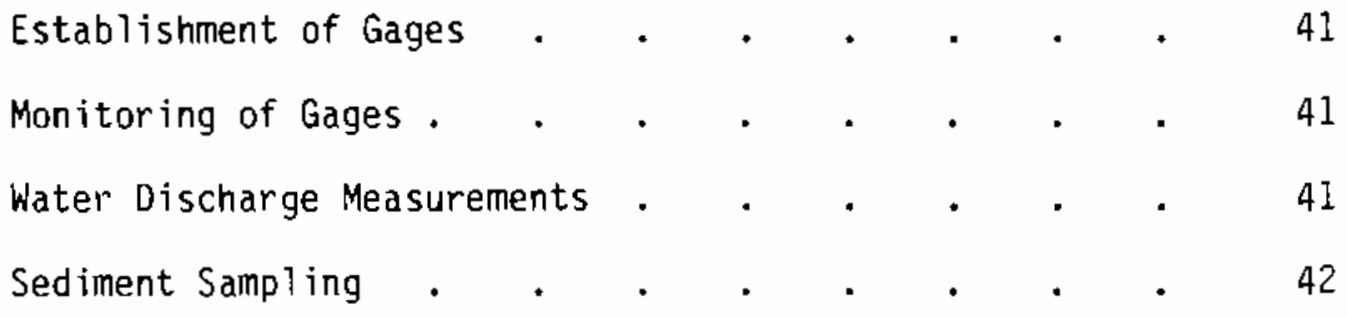




\section{FIGURES}

1 Franks-Buttermilk-Cattataugus Creek System with . . . . 6 Sampling Locations

2 Strontium-90 in Suspended Sediment . . . . . . . 11

3 Longitudinal Distributions of Suspended Particulate . . . 21 13 Cs Associated with Sand, Silt, Clay and Composite Sediment

4 Longitudinal Distributions of Suspended Particulate . . . 22 $235 \mathrm{U}$ Associated with Sand, Silt, Clay and Composite Sediment

5 Longitudinal Distributions of Suspended Particulate . . . 23 ${ }^{134}$ Cs Assocjated with Sand, Silt, Clay and Composite Sediment

$6 \quad$ Longitudinal Distributions of Suspended Particulate 226ra Associated with Sand, Silt, Clay and Composite Sediment

7 Longitudinal Distributions of Suspended Particulate . . . 25 228Th Associated with Sand, Silt, Clay and Composite Sediment

8 Longitudinal Distribution of Suspended Particulate . . . . 26 232Th Associated with Sand, Silt, Clay and Composite Sediment

9 Longitudinal Distribution of Particulate ${ }^{137} \mathrm{Cs}$. . . . 27 Associated with Bed Sediment of Sand, Silt, Clay and Composite Sediment

10 Longitudinal Distribution of Particulate ${ }^{134} \mathrm{Cs} \quad . \quad$. . . 28 Associated with Bed Sediment of Sand, Silt, Clay and Composite Sediment

11 Longitudinal Distribution of Particulate ${ }^{60} \mathrm{Co} \quad$. . . . 29 Associated with Bed Sediment of Sand, Silt, Clay and Composite Sediment

12 Longitudinal Distribution of Particulate $235 \mathrm{~J}$. . . . 30 Associated with Bed Sediment of Sand, Silt, Clay and Composite Sediment

13 Longitudinal Distribution of Particulate $226 \mathrm{Ra} . . . .$. Associated with Bed Sediment of Sand, Silt, Clay and Composite Sediment 
14 Longitudinal Distribution of Particulate ${ }^{228}$ Th $\quad$. . . . $\quad 32$ Associated with Bed Sediment of Sand, Silt, Clay and Composite Sediment

15 Longitudinal Distribution of Particulate 232Th . . . . . . 33 Associated with Bed Sediment of Sand, Silt, Clay and Composite Sediment

16 Gage Locations of Cattaraugas Creek and Tributaries, . . . 40 New York

17 Typical Staff Gage Installation for Recording Changes . . . . 42 in Water Surface Elevation

\section{TABLES}

1 Gamma Ray Spectrometry - Radionuclides Dissolved in Water . . 3 $(p \subset i / \ell)$

2 Garma Ray Spectrometry - Radionuclides Dissolved in Water * . 4-5 $(p C i / \ell)$

3 Strontium and Plutonium Attached to Suspended Sediment . . . 8 ( $\mathrm{pC} i / g$ )

4 Strontium and Plutonium Attached to Bed Sediment $(\mathrm{pC} i / g) \quad$ - $\quad 9$

5 Americium-241 and Curium-244 Analysis Performed by . . . . 13 the University of Washington

6 Gamma Ray Spectrometry Analysis--Radionuclides Adsorbed by 15-16 Suspended Sediment, Phase 2, Counted by the University of Washington

7 Gamma Ray spectrometry Analys is--Radionuclides Adsorbed by . 17-18 Bed Sediment, Phase 2, Counted by the University of Washington

8 Suspended Particulate Radionuclides of Gamma Emitters • . • 19

9 Weighted Average of Concentrations of Particulate . . . . . 20

10 Water Surface Stages, Connoisarauley Creek . . . . . . . 43

11 Water Surface Stages, Spooner Creek . . . . . . . . . . 44

12 Water Surface Stages, Spring Brook . . . . . . . . . 45 
13 Water Surface Stages, Franks Creek . . . . . . . . 46-47

14 Water Surface Stages, Buttermilk Creek . . . . . . . 48-49

15 Water Surface Stages, Cattaraugas Creek at Scobey . . . . 50

16 Water Surface Stages, Springville Dam - Cattaraugas _ . . 51 Creek

17 Water Surface Stages, Cattaraugas Creek at Bigelow . . . . 52 Bridge

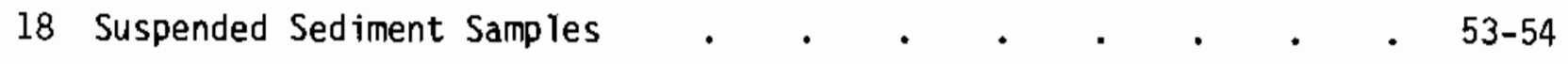

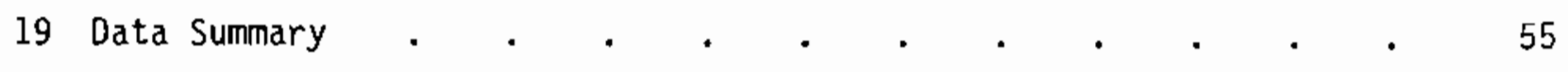





\section{PHASE 1 SAMPLING PROGRAM}

\section{RADIOLOGICAL ANALYSIS}

Radiological analyses were performed on sand, silt and clay sized fractions of suspended sediment, bed sediment and water samples. Priority was given to gamma ray spectrometry analysis during the Phase 1 sampling program because of initial funding limitations and the relatively low costs of gamma ray spectrometry. Additional funding allowed the analys is of other radionuclides requiring radiochemical separation procedures, such as ${ }^{90} \mathrm{Sr},{ }^{238} \mathrm{Pu}$, $239,240 \mathrm{Pu},{ }^{241} \mathrm{Am}$ and ${ }^{244} \mathrm{Cm}$. However, the high costs of radiochemical separation did not warrant the analysis of all samples for non-gamma radionuclides. Results of the Phase 1 study are reported in Ecker and Onishi (1979).

United States Testing, Inc., a commercial laboratory located in Richland, Washington, performed the majority of the gamma ray spectrometry, ${ }^{90} \mathrm{Sr},{ }^{238} \mathrm{Pu}$ and ${ }^{239} \mathrm{Pu}$ analyses of the Phase 1 samples. The University of Washington, Laboratory of Radiation Ecology also performed some gamma ray spectrometry,

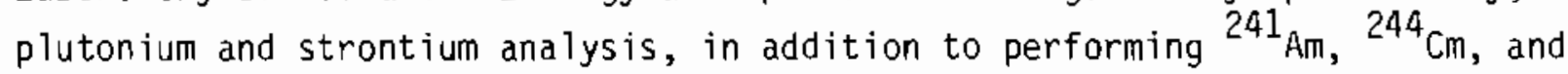
tritium analyses. PNL's Physical Sciences Department performed gamma ray spectrometry analysis of one sample ( $F C-1)$.

Gamma ray spectrometry analysis was performed using $\mathrm{Ge}(\mathrm{L} i)$ diode systems, except the one sample analyzed by PNL's Physical Sciences Department which utilized a large-volume NaI(TI) multi-dimensional gamma ray spectrometer system in the coincidence and noncoincidence modes (Ecker and Onishi 1979).

Gamma ray spectrometry analys is by U.S. Testing, Inc. utilized a Canberra Mode 7229 and 7248, Germanium-Lithium drifted diode and a Pulse Height Analyses (PHA) program for interpretation of the Ge(Li) spectra. The published detection limit of U.S. Testing's garma ray spectrometry analys is is $0.07 \mathrm{pCi} / \mathrm{g}$ based on a 500 minute count and $40 \mathrm{~g}$ of sample. For a 200 minute count the detection limit is $0.1 \mathrm{pCi} / \mathrm{g}$. The above detection limits do not apply to all samples analyzed, however, since the sample sizes were often less than $40 \mathrm{~g}$. In many cases, the suspended sand fraction and bed clay fraction quantities were less than $1 \mathrm{~g}$. In such cases, the detection limits increased dramatically 
and can be seen in the results of the gamma ray spectrometry analyses where the standard error (represented as \pm two standard deviations) is much greater than the mean value reported.

A description of methods and procedures used by U.S. Testing, Inc., in their gamma emitters, plutonium and strontium analyses of Phase 1 samples were described in detail in Ecker and Onishi (1979).

A description of the analytical methods and procedures used by the University of Washington, Laboratory of Radiation Ecology in their gamma ray spectrometry, plutonium, strontium, americium and curium analyses of the Phase 1 samples were also described in Ecker and Onishi (1979).

\section{GAMMA RAY SPECTROMETRY}

Tables 1 and 2 are the results of gamma ray spectrometry analys is of radionuclides dissolved in water. Gamma ray spectrometry results of dissolved radionuclides are reported as the total activity of a particular radionuclide (Table 1) and as the activity associated with each of the three resin beds, aluminum oxide beds and $0.3 \mu \mathrm{m}$ fiberglass filters (Table 2). Water samples were passed first through the filters, then through the aluminum oxide bed, and finally through resin (cation exchange) beds.

Transects $\mathrm{BC}-1$ and $\mathrm{CC}-1$ are the upstream control background stations on Buttermilk and Cattaraugus Creeks, as shown in Figure 1. Because these transects are upstream of the influence of the Nuclear Fuel Services, Inc. (NFS) complex at West Valley, New York, the radioactivity associated with the surface waters at these transects can be considered to be background. By comparing the gamma activity of water at the upstream control transects with the activity downstream of the NFS complex, one can, with a certain degree of confidence determine the influence of NFS facility on the radioactivity in Cattaraugus and Buttermilk Creeks.

\section{Gamma Activity Associated With Water}

Tables 1 and 2 are the results of gamma ray spectrometry analys is of radionuclides dissolved in water. In Table 2 , the results are reported as the 
TABLE 1. Gamma Ray Spectrometry - Radionuclides Dissolved in Water $(\mathrm{pC} i / \ell)$

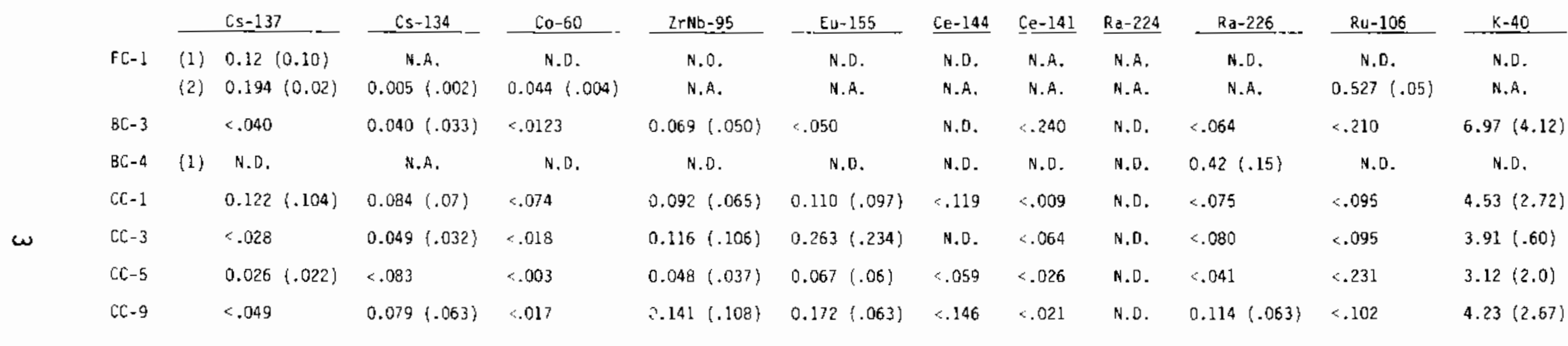

(1) University of Washington

Remaining samples analyzed by U.S. Testing

N.D. Not Detected

N.A. Not Analyzed

(i) Two Standard Deviations 
TABLE 2. Gamma Ray Spectrometry - Radionuclides Dissolved in Water (pCi/l)

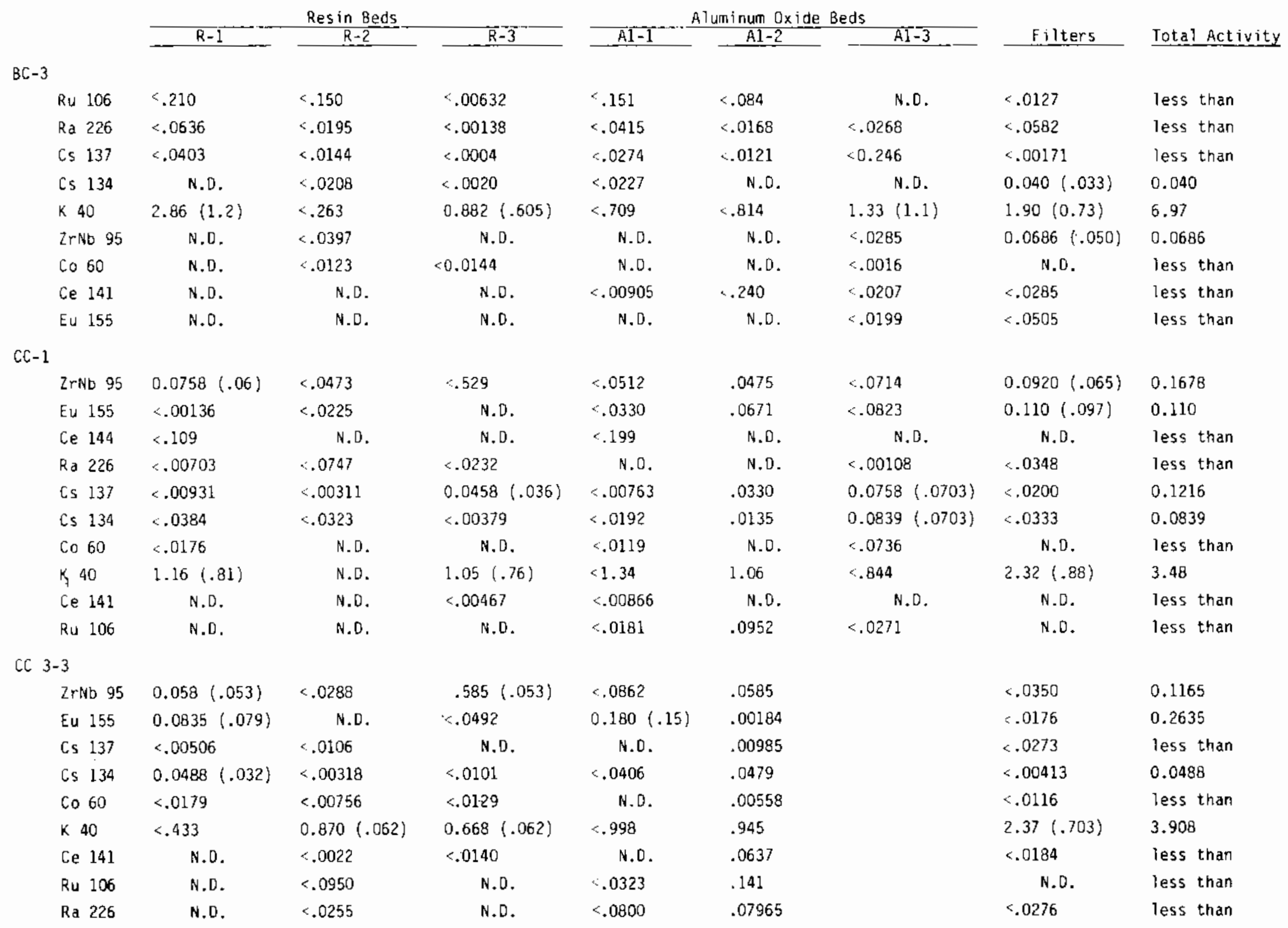


TABLE 2. (Continued)

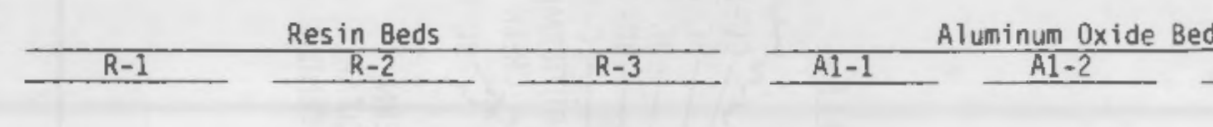

CC-5

ZrNb $95<.02$

Eu $155<.0545$

Ce $141<.0259$

Ra $226<.0213$

Cs $137<.0134$

CS $134<.0826$

K $40<.384$

N.

Ce 144 N.D.

Co 60

N.D.

N.D.

N.D.

$0.0478(.037)$

N.O.

0.0668
-.0118

$<.0318$

$<.0191$

$<.0096$

$<.0203$

$<.0019$

$0.582(.44)<.175$

Ru 106

$<.0588$

N.D.

$<.0009$

CC-9

\begin{tabular}{|c|c|c|c|}
\hline ZrNb 95 & $0.0607(0.53)$ & $0.0799(.053)$ & N.D. \\
\hline Eu 155 & $<.0809$ & $<.0720$ & N.D. \\
\hline Ce 144 & $<.146$ & $<.0650$ & $<.0304$ \\
\hline Ce 141 & $<.0206$ & N.0. & N.D. \\
\hline Cs 137 & $<.0203$ & $<.0039$ & $<.0146$ \\
\hline Cs 134 & $<.0316$ & $<.0259$ & $<.0150$ \\
\hline Co 60 & $<.0169$ & N.O. & $<.0088$ \\
\hline K 40 & $0.881 \quad(.722)$ & $<.496$ & $0.857(.674)$ \\
\hline Ru 106 & N.D. & $<.0024$ & $<.0006$ \\
\hline $\mathrm{Ra} 226$ & N.D. & $<.0010$ & $<.0100$ \\
\hline
\end{tabular}

N.0.

$<.0404$

N.D.

$<.0869$

$<.0088$

N.D.

$<.0178$

$<.0408$

$<.0071$

$<.0037$

$<.0161$

$<.0303$

$<.0092$

$<.0033$

.0072

$<.775$

0.949 (.

$<.0282$

N.D.

N. 0 .

$<.231$

$\begin{array}{ll}\text { N.D. } & \text { N.D. } \\ \text { N.D. } & <.0022 \\ \text { N.D. } & <.108\end{array}$

$<.0187$

N.D.

$<.0949$

$<.0254$

$<.0410$

$0.172(.065)$

N.D.

N.O.

N. 0 .

$<.0237$

$<.0013$

$<.0006$

$<.0103$

$<.0016$

$<.0492$

$0.0791(.063)$

$<.0021$

$<.612$

$<.0024$

$<.243$

N.D.

$<.0689$

$<.0255$

$<.0329$

$<.0322$

Filters

Total Activity

$<.0101$

$\begin{array}{cl}<.0252 & 0.0478 \\ N . D . & 0.0668 \\ N .0 . & l e s s \text { than } \\ <.0266 & \text { less than } \\ 0.0260(.022) & 0.0260 \\ <.0136 & l \text { less than } \\ 1.59(.50) & 3.12 \\ N . D . & \text { less than } \\ <.0026 & \text { less than } \\ <.0555 & \text { less than } \\ & \\ <.0067 & 0.1406 \\ N . D . & 0.172 \\ N . D . & \text { less than } \\ <.0204 & \text { less than } \\ <.0143 & \text { less than } \\ <.0213 & 0.0791 \\ N . D . & \text { less than } \\ 2.49(.722) & 4.23 \\ <.1020 & \text { less than } \\ 0.114(.063) & 0.114\end{array}$

$<.025$

N.0. less than

$0.0260(.022) \quad 0.0260$

$<.0136$ less than

$1.59(.50) \quad 3.12$

N.D. less than

ss than

1406

172

ss than

ss than

114

N.D. Not detected

( ) \pm two standard deviations

R-1 through R-3 Resin Beds

Al-1 through Al-3 Aluminum 0xide Beds 


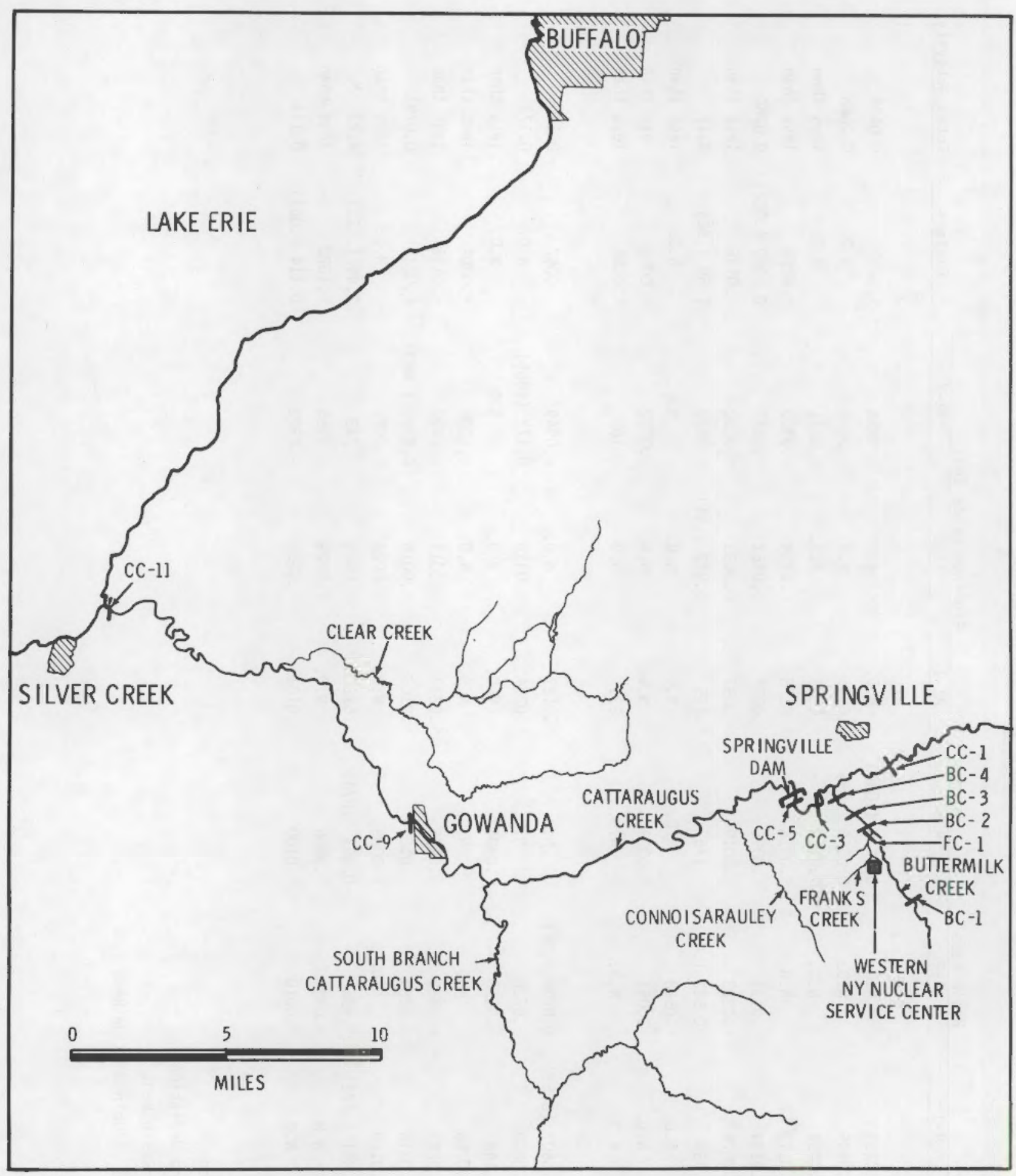

FIGURE 1. Franks-Buttermilk-Cattraugus Creek System with Sampling Locations 
gamma activity associated with each of the resin beds, aluminum oxide beds, filters and total activity. The gamma activity in water was very low during the Phase 1 sampling program. Even ${ }^{137} \mathrm{Cs}$ levels in water were difficult to distinguish from the levels in the upstream control transect on Cattaraugus Creek. The counting errors as indicated by two standard deviations, in most cases, were very large compared with the reported likely value, even though some of the samples were counted for 2000 minutes. These large counting errors are not only a result of the low levels of activity, but also due to the size of the water sample taken. A different method for collection of large volume water samples, used during the Phase 2 sampling program, allowed larger water samples to be taken in the field and thus increased sensitivity.

Results of gamma ray spectrometry analysis in Cattaraugus and Buttermilk Creeks indicate that during the Phase 1 sampling program in November and December 1977, the principal gamma emitting radionuclide with levels downstream of the NFS complex was ${ }^{137}$ CS. However, even for Cesium-137, its levels in water were very low and in only a few cases were they above detection. Results of Phase 1 sample analyses reveal that the levels of gamma emitters other than ${ }^{137} \mathrm{Cs}$, in a few cases, were greater in downstream samples than in background

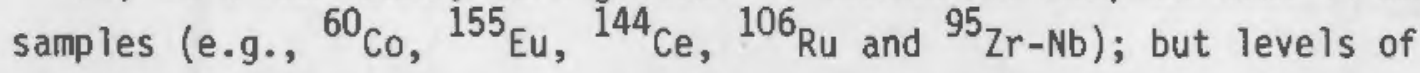
these samples were too near the background levels, or the number of cases were too small in number to provide an accurate evaluation.

\section{PLUTONIUM AND STRONTIUM ANALYSIS}

Results of ${ }^{238} \mathrm{Pu}, 239,240 \mathrm{Pu}$, and ${ }^{90} \mathrm{Sr}$ analyses of suspended sediment and bed sediment for Phase 1 are summarized in Tables 3 and 4 . Only two water samples, $\mathrm{FC}-1$ and $\mathrm{BC}-4$ were analyzed for $\mathrm{Pu}$ and $\mathrm{Sr}$ for reasons stated previously. The ${ }^{238} \mathrm{Pu}$ and ${ }^{239,240} \mathrm{Pu}$ in water of Franks Creek (FC-1) were $0.0134 \pm$ $0.0026 \mathrm{pCi} / \ell$ and $0.0020 \pm 0.0010 \mathrm{pCi} / \ell$, respectively. The levels in water of $\mathrm{BC}-4$, Thomas Corners Bridge on Buttermilk Creek were $0.0154 \pm 0.003 \mathrm{pCi} / \ell$ and $0.0038 \pm 0.0015 \mathrm{pC} i / \ell$, respectively.

Plutonium and Strontium in Suspended Sediment

Very few suspended sediment samples had detectable levels of ${ }^{238} \mathrm{Pu}$, and all these were found in Franks Creek and Buttermilk Creek. The highest ${ }^{238} \mathrm{Pu}$ 
TABLE 3. Strontium and Plutonium Attached to Suspended Sediment $(p C i / g$ )

\begin{tabular}{|c|c|c|c|}
\hline & $238 p_{u}$ & $239-240 \mathrm{pu}$ & ${ }^{90} \mathrm{sr}$ \\
\hline $\begin{array}{r}\mathrm{FC}-1 \text { (UW) } \\
\text { Sand } \\
\text { Silt } \\
\text { Clay }\end{array}$ & $\begin{array}{l}\text { N.A. } \\
0.0074(0.0007) \\
0.0344(.0028)\end{array}$ & $\begin{array}{l}\text { N.A. } \\
0.0013(.0004) \\
0.0139(.0017)\end{array}$ & $\begin{array}{l}\text { N.D. } \\
<0.013 \\
\text { N.D. }\end{array}$ \\
\hline $\begin{array}{r}\mathrm{BC}-1 \text { (UW) } \\
\text { Sand } \\
\text { Silt } \\
\mathrm{Clay}\end{array}$ & $\begin{array}{l}\text { N.A. } \\
0.0153(.0040) \\
\text { N.A. }\end{array}$ & $\begin{array}{l}\text { N.A. } \\
0.0024(.0023) \\
\text { N.A. }\end{array}$ & $\begin{array}{l}\text { N.A. } \\
<0.029 \\
\text { N.A. }\end{array}$ \\
\hline $\begin{array}{l}\text { BC2-1 } \\
\text { Sand } \\
\text { Silt } \\
\text { Clay }\end{array}$ & $\begin{array}{l}0.0262(.023) \\
\text { N.A. } \\
\text { N.D. }\end{array}$ & $\begin{array}{l}<.00818 \\
\text { N.A. } \\
\text { N.A. }\end{array}$ & $\begin{array}{l}0.147(.0044) \\
0.230(.014) \\
1.02(.18)\end{array}$ \\
\hline $\begin{array}{l}\text { BC3-1 } \\
\text { Sand } \\
\text { Silt } \\
\text { Clay }\end{array}$ & $\begin{array}{l}\text { N.D. } \\
0.236(.16) \\
\text { N. } 0 .\end{array}$ & $\begin{array}{l}<1.58 \\
<.107 \\
<.0042\end{array}$ & $\begin{array}{l}<1.68 \\
1.15(.066) \\
1.18(.38)\end{array}$ \\
\hline $\begin{array}{l}\text { BC4-1 } \\
\text { Sand } \\
\text { Silt } \\
\text { Clay }\end{array}$ & $\begin{array}{l}\text { N.D. } \\
\text { N.D. } \\
\text { N.D. }\end{array}$ & $\begin{array}{l}<.0304 \\
<.003 \\
<.019\end{array}$ & $\begin{array}{l}1.40(1.0) \\
2.27(.092) \\
1.06(.31)\end{array}$ \\
\hline $\begin{array}{c}\text { CC3-1/.2d } \\
\text { silt } \\
\text { Clay }\end{array}$ & $\begin{array}{l}<.024 \\
\text { N.D. }\end{array}$ & $\begin{array}{l}0.0988(.049) \\
\text { N.D. }\end{array}$ & $\begin{array}{l}2.40(.12) \\
0.819(.61)\end{array}$ \\
\hline $\begin{array}{c}\mathrm{CC} 3-1 / .5 d \\
\text { Sand } \\
\text { Silt } \\
\text { Clay }\end{array}$ & $\begin{array}{l}\text { N.D. } \\
\text { N.D. } \\
\text { N.D. }\end{array}$ & $\begin{array}{l}\text { N.0. } \\
<.00478 \\
<.017\end{array}$ & $\begin{array}{l}0.757(.36) \\
0.354(.038) \\
1.01(.56)\end{array}$ \\
\hline $\begin{array}{l}\text { CC3-2 } \\
\text { Sand }\end{array}$ & N.D. & N.D. & $<.64$ \\
\hline $\begin{array}{r}\text { CC5-1 } \\
\text { Sand } \\
\text { Silt } \\
\text { Clay }\end{array}$ & $\begin{array}{l}\text { N.D. } \\
\text { N.D. } \\
\text { N.D. }\end{array}$ & $\begin{array}{l}\text { N.D. } \\
\text { N.D. } \\
\text { N.D. }\end{array}$ & $\begin{array}{l}10.1(4.5) \\
2.66(.13) \\
0.770(.28)\end{array}$ \\
\hline $\begin{array}{c}\text { CC5-2/.5d } \\
\text { Sand } \\
\text { Silt }\end{array}$ & $\begin{array}{l}\text { N.D. } \\
\text { N.D. }\end{array}$ & $\begin{array}{l}\text { N.D. } \\
<.0013\end{array}$ & $\begin{array}{ll}7.21 & (4.5) \\
1.84(.092)\end{array}$ \\
\hline $\begin{array}{l}\text { CC9-1 } \\
\text { Sand } \\
\text { Silt } \\
\text { Clay }\end{array}$ & $\begin{array}{l}<.00235 \\
\text { N. } 0 . \\
\text { N.D. }\end{array}$ & $\begin{array}{l}\text { C.0163 } \\
\text { N.D. } \\
\text { N.D. }\end{array}$ & $\begin{array}{l}0.717(.33) \\
2.17(.11) \\
0.931(.45)\end{array}$ \\
\hline $\begin{array}{c}\text { C11-1/.8d } \\
\text { Silt } \\
\text { Clay }\end{array}$ & $\begin{array}{l}\text { N.D. } \\
\text { N.D. }\end{array}$ & $\begin{array}{l}<.0056 \\
<.0398\end{array}$ & $\begin{array}{l}1.55(.077) \\
0.788(.56)\end{array}$ \\
\hline
\end{tabular}


TABLE 4. Strontium and Plutonium Attached to Bed Sediment $(\mathrm{pCi} / \mathrm{g})$

\begin{tabular}{|c|c|c|c|}
\hline & ${ }^{238} \mathrm{Pu}$ & $239,240 \mathrm{Pu}$ & ${ }^{90} \mathrm{Sr}$ \\
\hline $\begin{array}{r}\text { FC-1(UW) } \\
\text { Sand } \\
\text { Silt } \\
\text { Clay }\end{array}$ & $\begin{array}{l}0.0051 \quad(.0009) \\
N . A . \\
0.0028(.0009)\end{array}$ & $\begin{array}{l}0.0030(.0006) \\
N . A . \\
0.0003(.0010)\end{array}$ & $\begin{array}{l}<0.042 \\
<0.022 \\
<0.028\end{array}$ \\
\hline $\begin{array}{c}\text { BC-1 (UW) } \\
\text { Sand } \\
\text { Silt } \\
\text { Clay }\end{array}$ & $\begin{array}{l}0.0020(.0004) \\
0.0613(0.0161) \\
0.0051(0.0023)\end{array}$ & $\begin{aligned} & 0.0006(.0002) \\
& 0.0239(0.0093) \\
&<0.0014\end{aligned}$ & $\begin{array}{l}<.013 \\
<.03 \\
\text { N.D. }\end{array}$ \\
\hline $\begin{array}{r}\text { BC2-1 } \\
\text { Sand } \\
\text { Silt } \\
\text { Clay }\end{array}$ & $\begin{array}{l}\text { N.D. } \\
\text { N.D. } \\
\text { N.D. }\end{array}$ & $\begin{array}{l}\text { N.D. } \\
\text { N.D. } \\
<0.680\end{array}$ & $\begin{aligned} & 0.0721(0.045) \\
0.315(0.045) & <0.592\end{aligned}$ \\
\hline $\begin{array}{l}\text { BC3-1 } \\
\text { Sand } \\
\text { Silt } \\
\text { Clay }\end{array}$ & $\begin{array}{l}\text { N.D. } \\
<0.0681 \\
\text { N.D. }\end{array}$ & $\begin{array}{l}<0.0008 \\
<0.0487 \\
\text { N.D. }\end{array}$ & $\begin{array}{ll}0.237 & (0.045) \\
0.234 & (0.045) \\
3.38 & \end{array}$ \\
\hline BC4 Mixed Bed (UW) & $0.0059(.0018)$ & $0.0065(.0016)$ & N.A. \\
\hline $\begin{array}{l}\text { BC4-1 } \\
\text { Sand } \\
\text { Clay }\end{array}$ & $\begin{array}{l}\text { N.D. } \\
\text { N.D. }\end{array}$ & $\begin{array}{l}<0.284 \\
<0.210\end{array}$ & $\begin{array}{l}<0.330 \\
0.243(0.045)\end{array}$ \\
\hline CC3 Mixed Bed (UW) & $0.0039(.0011)$ & $0.0025(.0010)$ & \\
\hline $\begin{array}{l}\text { CC3-1 } \\
\text { Sand } \\
\text { Silt } \\
\text { Clay }\end{array}$ & $\begin{array}{l}\text { N.D. } \\
\text { N.D. } \\
\text { N.D. }\end{array}$ & $\begin{array}{l}\text { N.D. } \\
\text { N.D. } \\
<0.473\end{array}$ & $\begin{array}{l}<0.030 \\
0.0480(.045) \\
<4.50\end{array}$ \\
\hline $\begin{array}{l}\mathrm{CC} 3-2 \\
\text { Sand } \\
\text { Silt } \\
\text { Clay }\end{array}$ & $\begin{array}{l}\text { N.D. } \\
\text { N.D. } \\
\text { N.D. }\end{array}$ & $\begin{array}{l}\text { N.D. } \\
\text { N.D. } \\
<.0819\end{array}$ & $\begin{array}{l}<.0420 \\
<0.0150 \\
<1.22\end{array}$ \\
\hline $\begin{array}{l}\text { Cc9-1 } \\
\text { Sand } \\
\text { Silt } \\
\text { Clay }\end{array}$ & $\begin{array}{l}\text { N.D. } \\
\text { N.D. } \\
\text { N.D. }\end{array}$ & $\begin{array}{l}<.00687 \\
\text { N.D. } \\
\text { N.D. }\end{array}$ & $\begin{aligned} 0.0841 & (0.045) \\
0.0480(0.045) & (0.287\end{aligned}$ \\
\hline $\begin{array}{l}\text { N.A. Not AnaTyzed } \\
\text { N.D. Not Detected } \\
(\text { ) } \pm \text { one standard }\end{array}$ & tion & & 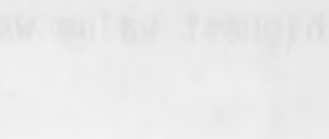 \\
\hline
\end{tabular}


value was found associated with the suspended silt fraction of BC3-1 $(0.236 \pm$ $0.16 \mathrm{pCi} / \mathrm{g}$ ). At $\mathrm{FC}-1$ the suspended silt and clay fractions had ${ }^{238} \mathrm{Pu}$ levels of $0.0074+0.0008 \mathrm{pCi} / \mathrm{g}$ and $0.0344 \pm 0.0028 \mathrm{pCi} / \mathrm{g}$, respectively. Detectable levels of ${ }^{238} \mathrm{Pu}$ were also found in the suspended sand fraction of $\mathrm{BC}-2$, station 1 and the suspended silt fraction of $\mathrm{BC}-1$.

Detectable levels of ${ }^{239,240} \mathrm{Pu}$ in suspended sediment were found only at $\mathrm{FC}-1, \mathrm{BC}-1$ and near the surface of $\mathrm{CC}-3$, station 1. The highest ${ }^{239,240} \mathrm{Pu}$ value of $0.0988 \pm 0.049 \mathrm{pCi} / \mathrm{g}$ was found in the suspended sand fraction of $\mathrm{CC}-3$, station 1. The suspended silt and clay fractions of $\mathrm{FC}-1$ had ${ }^{239,240} \mathrm{Pu}_{\mathrm{u}}$ levels of $0.0013 \pm 0.0004 \mathrm{pCi} / \mathrm{g}$ and $0.0139 \pm 0.0017 \mathrm{pCi} / \mathrm{g}$, respectively.

Detectable levels of ${ }^{90} \mathrm{Sr}$ in suspended sediment were found at most transects. The highest recorded value was found in the suspended sand fraction of $\mathrm{CC}-5$, station 1 in Springville Reservoir with a ${ }^{90} \mathrm{Sr}$ value of $10.1 \pm 4.5 \mathrm{pCi} / \mathrm{g}$.

Figure 2 is a comparison of ${ }^{90} \mathrm{Sr}$ levels in the suspended sand, silt and clay fractions of Phase 1 samples. The highest ${ }^{90} \mathrm{Sr}$ levels in suspended sediment were found in Springville Reservoir (CC-5) on Cattaraugus Creek. Strontium-90 levels in the suspended sediment of Cattaraugus Creek were as high or higher than those in suspended sediment of Buttermilk and Franks Creeks.

\section{Plutonium and Strontium in Bed Sediment}

Table 4 is a summary of ${ }^{238} \mathrm{Pu},{ }^{239}, 240 \mathrm{Pu}$ and ${ }^{90} \mathrm{Sr}$ levels in bed sediment of Cattaraugus and Buttermilk Creeks during the Phase 1 sampling program. Very few bed sediment samples had detectable levels of ${ }^{238} \mathrm{Pu}$ and $239,240 \mathrm{Pu}$. The highest ${ }^{238} \mathrm{Pu}$ value was found in the bed silt fraction of $B C-1(0.0613 \pm 0.0161 \mathrm{pCi} / \mathrm{g})$. The bed sand fraction of $\mathrm{FC}-1$, bed clay fraction of $\mathrm{BC}-1$ and mixed bed sample of $\mathrm{BC}-4$ had similar ${ }^{238} \mathrm{Pu}$ levels.

The only bed sediment samples with detectable levels of $239,240 \mathrm{Pu}$ were found at $\mathrm{FC}-1, \mathrm{BC}-4$ (mixed bed), $\mathrm{BC}-1$ and $\mathrm{CC}-3$ mixed bed. The highest $239,240 \mathrm{Pu}$ value of $0.0129 \pm 0.0093 \mathrm{pCi} / \mathrm{g}$ was found in the bed silt fraction of $\mathrm{BC}-1$, the upstream control transect on Buttermilk Creek. Strontium-90 levels in bed sediment varied from below detection to $0.315 \pm 0.045 \mathrm{pCi} / \mathrm{g}$. The highest value was found at $\mathrm{BC}-2$, station 1 in the bed silt fraction. 
$\mathrm{pCi} / \mathrm{g}$

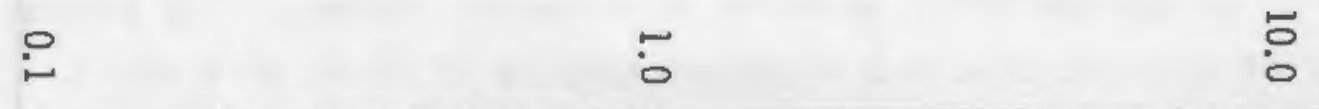

FC-1

SAND - NONE DETECTED

SILT - $\angle 0.013$

CLAY - NONE DETECTED

$\mathrm{BC}-$

SAND - NOT ANALYZED

SILT - $\angle 0.029$

CLAY - NONE DETECTED

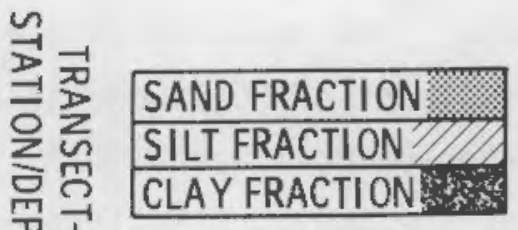

$\mathrm{BC} 2-1$

20100म

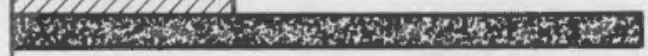

코

SAND $<1.68$

BC3-1

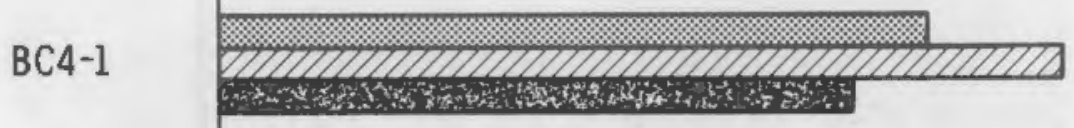

SAND - NONE DETECTED

$\operatorname{cc} 3-1 / .2 \mathrm{~d}$

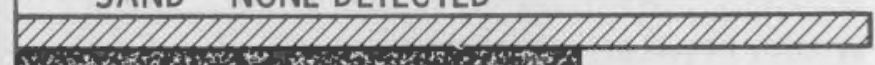

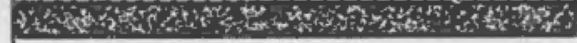

$\operatorname{cc} 3-11.5 d$

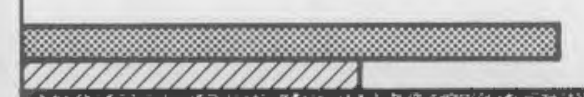

Fins

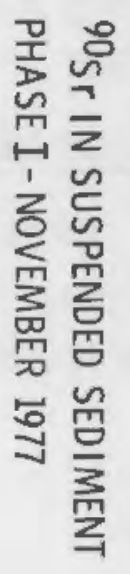

CC5-1

cC5-21.5d

CC9-1

CC11-1/.8d

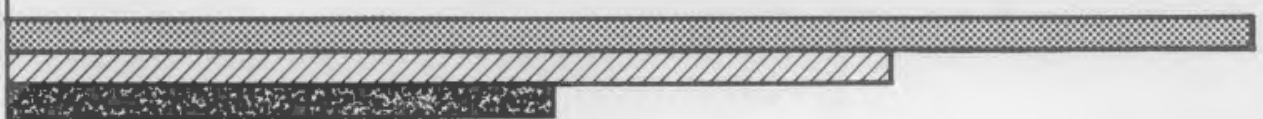

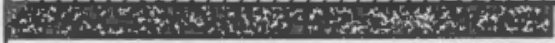

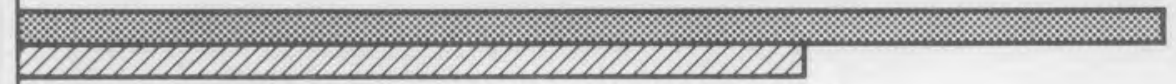

CLAY - NONE DETECTED

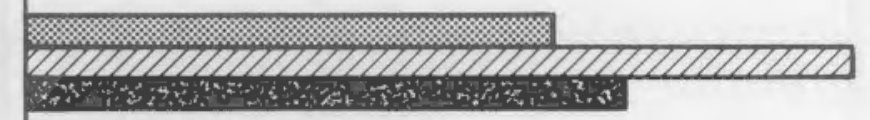

SAND- NONE DETECTED

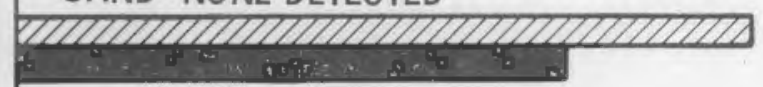

FIGURE 2. Strontium-90 in Suspended Sediment 
AMERICIUM AND CURIUM ANALYSIS

Americium-241 and ${ }^{244} \mathrm{Cm}$ analys is of suspended sediment, bed sediment and water of $F C-1$ and $B C-1$ and mixed bed samples of $B C-4, C C-3$ and $C C-11$, were performed by the University of Washington. The results of these analyses are summarized in Table 5 . The highest ${ }^{241}$ Am levels were found in the bed clay fraction of $\mathrm{BC}-1$ with a value of $1.00 \pm 0.30 \mathrm{pCi} / \mathrm{g}$. The suspended clay sample of $B C-1$ had a ${ }^{241} \mathrm{Am}$ value of $0.94 \pm 0 . \overrightarrow{31} \mathrm{pCi} / \mathrm{g}$. Americium-241 levels in suspended sediment of $F C-1$ were less than the counting error. The ${ }^{241} \mathrm{Am}$ value in water of $\mathrm{FC}-1$ was $0.00163 \pm 0.00024 \mathrm{pCi} / \mathrm{g}$. The mixed bed sample

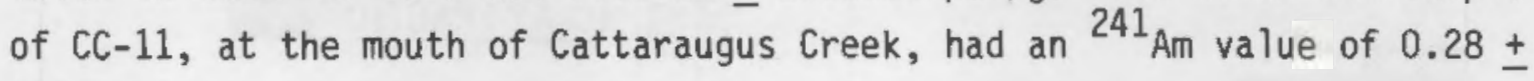
$0.06 \mathrm{pCi} / \mathrm{g}$.

The highest ${ }^{244} \mathrm{Cm}$ value was found in the suspended clay fraction of $\mathrm{FC}-1$ $(1.29 \pm 0.08 \mathrm{pCi} / \mathrm{g})$. Curium-244 value in the water of $\mathrm{BC}-4$ was $0.00004 \pm$ $0.00002 \mathrm{pCi} / \mathrm{l}$.

TRITIUM ANALYSIS

Three water samples, located at $B C-4, C C-3$ and $C C-11$ were analyzed for tritium. The tritium levels in these water samples were $461 \pm 35 \mathrm{pCi} / \ell, 305 \pm$ $36 \mathrm{pCi} / \ell$ and $206 \pm 32 \mathrm{pCi} / \ell$, respectively. 
TABLE 5. Americium-241 and Curium-244 Analysis Performed by the University of 'Washington ( $\mathrm{pC} i / g$ for particulates and $\mathrm{pC} i / \ell$ for dissolved radionuclides)

\begin{tabular}{|c|c|c|}
\hline & ${ }^{241} \mathrm{Am}$ & ${ }^{244} \mathrm{Cm}$ \\
\hline \multicolumn{3}{|l|}{$\mathrm{FC}-1$} \\
\hline Suspended Sand & NA & NA \\
\hline Suspended Silt & $<0.06$ & $0.05(0.01)$ \\
\hline Suspended Clay & $<0.18$ & $1.29(0.08)$ \\
\hline Bed Sand & $0.40(0.07)$ & $0.28(0.02)$ \\
\hline Bed Silt & $0.23(0.06)$ & $0.24(0.02)$ \\
\hline Bed Clay & $0.74(0.13)$ & $0.30(0.03)$ \\
\hline Water & $0.00163(0.00024)$ & $<0.00002$ \\
\hline \multicolumn{3}{|l|}{$\mathrm{BC}-1$} \\
\hline Suspended Sand & NA & NA \\
\hline Suspended Silt & $0.47(0.13)$ & $0.50(0.04)$ \\
\hline Suspended Clay & $0.91(0.31)$ & $0.64(0.05)$ \\
\hline Bed Sand & $0.26(0.04)$ & $0.29(0.03)$ \\
\hline Bed Silt & $0.28(0.13)$ & $0.24(0.03)$ \\
\hline Bed Clay & $1.00(0.30)$ & $0.59(0.04)$ \\
\hline \multicolumn{3}{|l|}{$B C-4$} \\
\hline Mixed Bed & $0.20(0.04)$ & $0.29(0.03)$ \\
\hline Water & $<0.00046$ & $0.00004(0.00002)$ \\
\hline \multicolumn{3}{|l|}{$\mathrm{CC}-3$} \\
\hline Mixed Bed & $<0.04$ & $<0.01$ \\
\hline \multicolumn{3}{|l|}{$C C-11$} \\
\hline Mixed Bed & $0.28(0.06)$ & $0.18(0.02)$ \\
\hline
\end{tabular}

N.A. Not analyzed due to insufficient quantity of sample ( ) \pm one standard deviation 


\section{PHASE 2 SAMPLING PROGRAM}

RADIOLOGICAL ANALYSIS

Similar to the Phase 1 Program, radiological analyses were performed on sand, silt and clay size fractions of suspended sediment and bed sediment; and for water. All radiological counting was performed by the University of Washington, Laboratory of Radiation Ecology.

Particulate radionuclides described by three sediment size fractions (sand, silt and clay) of suspended and bed sediments counted by the University of Washington, are shown in Tables 6 and 7. Sampling locations are shown in Figure 1 .

Based on the percentage of each sediment size fraction for both suspended and bed sediments, weighted-average particulate radionuclide concentrations were calculated and results are shown in Tables 8 and 9 . Changes of suspended particulate radionuclide concentrations associated with sand, silt, clay and composite suspended sediment with respect to the river locations are shown in Figures 3 through 8 . Vertical lines in these figures indicate the range of two standard deviations. Each cesium-137 distribution associated with clay, silt and composites sediments shown in Figure 3 , has a sharp peak at the mouth of the Franks Creek, revealing the introduction of ${ }^{137} \mathrm{Cs}$ from NFS into the Buttermilk-Cattaraugus Creek system. This figure also indicates that ${ }^{137} \mathrm{Cs}$ associated with clay has consistantly a several times higher concentration than one associated with silt at the same location. This may be due to a higher exchange capacity of clay as compared to silt's capacity. Uranium-235 associated with the composite sediment also reveals a small peak at $\mathrm{FC}-1$ as shown in Figure 4. Cesium-134, radium-226, thorium-228 and thorium-232 do not show any discernible peaks releated to radionuclides released to Buttermilk-Cattaraugus Creek system from the Franks Creek, as shown in Figures 5 through 8.

Similarly, particulate radionuclides associated with sand, silt, clay and composite sediment in the river bed are shown in Figures 9 through 15 . Cesium137, shown in Figure 9, clearly indicates that concentrations in Erdmans Brook (which is a tributary of Franks Creek closest to the NFS disposal site) and Franks Creek are the highest for all the three sediment size fractions as 
TABLE 6. Gamma Ray Spectrometry Analysis--Radionuclides Adsorbed by Suspended Sediment, Phase 2, counted by the University of Washington

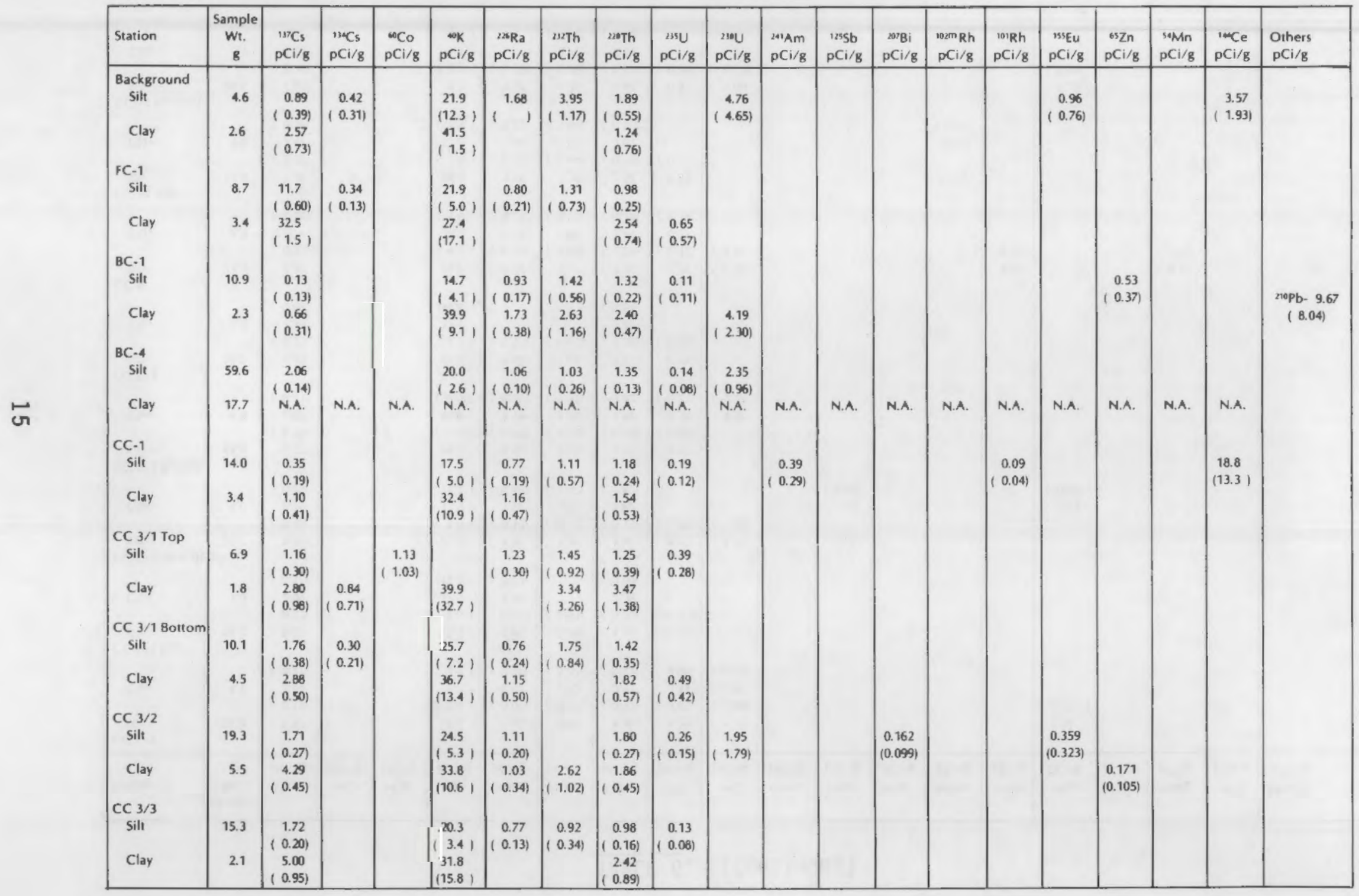


TABLE 6. (Continued)

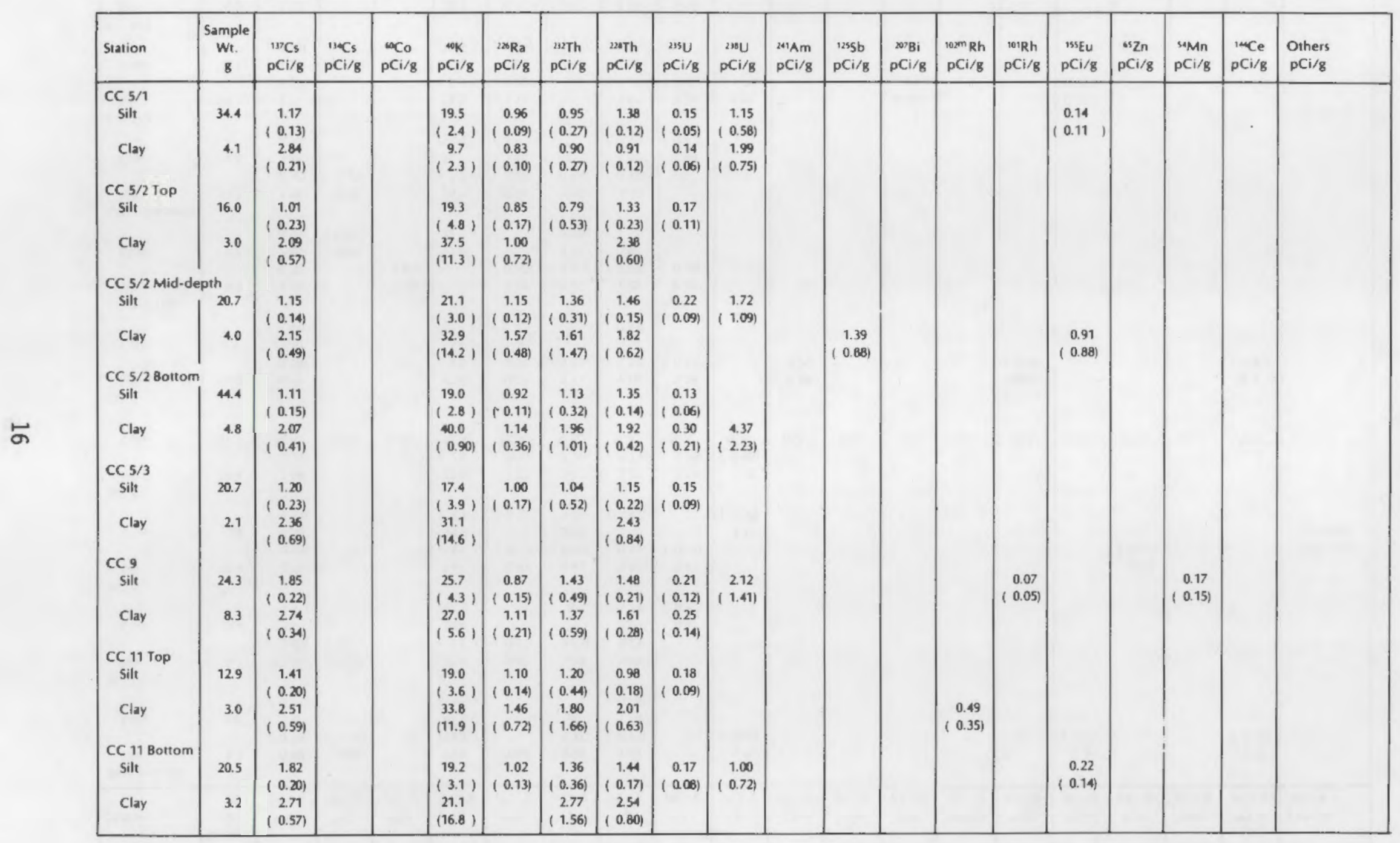

N.A. - Not analyzed.

Blanks indicate a radionuclide level was below detection.

(1) parentheses represent two standard deviations. 
TABLE 7. Gamma Ray Spectrometry Analysis--Radionuclides Adsorbed by Bed Sediment Phase 2, Counted by the University of Washington

\begin{tabular}{|c|c|c|c|c|c|c|c|c|c|c|c|c|c|c|c|c|c|c|c|c|}
\hline $\begin{array}{l}\text { Station } \\
\text { Fraction }\end{array}$ & * & $\begin{array}{l}13 \mathrm{Cs} \\
\mathrm{pCi} / \mathrm{g}\end{array}$ & $\begin{array}{l}19 \mathrm{Cs} \\
\mathrm{pCi} / \mathrm{g}\end{array}$ & $\begin{array}{l}{ }_{\mathrm{pCl} / \mathrm{g}} \mathrm{Co} \\
\end{array}$ & ${ }_{\mathrm{pCi} i \mathrm{~K}}^{+0 \mathrm{~K}}$ & $\begin{array}{l}2 x_{R a} \\
p C i / g\end{array}$ & $\begin{array}{l}2 ! \text { Th } \\
\rho C i / g\end{array}$ & $\begin{array}{l}2 a \mathrm{Th} \\
\mathrm{DCl} \mathrm{i} / \mathrm{g}\end{array}$ & $\begin{array}{l}215 \mathrm{U} \\
\mathrm{pC} \text { Ci/g }\end{array}$ & ${ }_{\mathrm{pCi} / \mathrm{g}}^{2 \mathrm{U}}$ & $\begin{array}{l}2 a 1 \mathrm{Am} \\
\mathrm{pCi} / \mathrm{g}\end{array}$ & $\begin{array}{l}1255 b \\
p^{2} \mathrm{Ci} / \mathrm{g}\end{array}$ & $\begin{array}{c}w^{2} \mathrm{Bi} \\
\mathrm{pCi} / \mathrm{g}\end{array}$ & $\begin{array}{l}{ }^{100 m} R h \\
\rho C_{i} / / g\end{array}$ & $\begin{array}{l}\text { 10'Rh } \\
\mathrm{pCi} / \mathrm{g}\end{array}$ & $\begin{array}{c}9 \mathrm{Cr} \\
\mathrm{pCi} / \mathrm{g}\end{array}$ & $\begin{array}{l}\text { 155Eu } \\
\text { pCi/8 }\end{array}$ & $\begin{array}{l}\mathrm{s} \mathrm{Zn} \\
\mathrm{pCi} / \mathrm{g}\end{array}$ & $\begin{array}{l}{ }^{50} \mathrm{Mn} \\
\mathrm{pCi} / \mathrm{g}\end{array}$ & $\begin{array}{l}\text { Other } \\
\mathrm{pCi} / \mathrm{g}\end{array}$ \\
\hline \multirow{2}{*}{$\begin{array}{l}\text { FC-1 } \\
\text { Sand }\end{array}$} & & & & & & & & & & & & & & & & & & & & \\
\hline & 74.5 & $\left(\begin{array}{c}27.7 \\
(0.50)\end{array}\right.$ & $\mid \begin{array}{l}0.47 \\
(0.07)\end{array}$ & $\begin{array}{c}0.44 \\
(0.08\}\end{array}$ & $\begin{array}{l}14.1 \\
(2.0)\end{array}$ & $\begin{array}{r}0.51 \\
0.09\end{array}$ & $\begin{array}{r}0.47 \\
0.321\end{array}$ & $\begin{array}{l}0.59 \\
0.71\end{array}$ & 0.08 & 0.91 & & & & & & & & & & \\
\hline \multirow{2}{*}{ Silt } & 23.2 & 28.6 & 0.52 & 0.45 & 15.5 & $\begin{array}{c}0.091 \\
0.84\end{array}$ & $\begin{array}{c}10.321 \\
0.62\end{array}$ & $\left(\begin{array}{c}0.711 \\
1.04\end{array}\right.$ & $\left(\begin{array}{c}0.06) \\
0.16\end{array}\right.$ & $\begin{array}{r}(0.59) \\
0.82\end{array}$ & & & 0.11 & & & & & & & \\
\hline & & $\left(\begin{array}{ll}1 & 0.60)\end{array}\right.$ & $(0 . \infty)$ & $(0.08)$ & (2.2) & $(0.11)$ & $(0.42)$ & $(0.13)$ & $(0.00)$ & $(0.72)$ & & & $(0.07)$ & & & & & & & \\
\hline \multirow[t]{2}{*}{ Clay } & 2.3 & 134.0 & 2.81 & 1.91 & 39.2 & 1.74 & 2.22 & 2.31 & 0.57 & 3.57 & & 1.84 & & 0.25 & & & & & & \\
\hline & & $10.90\}$ & $(1.46)$ & $(0.14)$ & (3.4) & $(0.18)$ & ( 0.63$)$ & $(0.22)$ & $(0.14)$ & (1.52) & & $(0.59)$ & & $(0.20)$ & & & & & & \\
\hline \multirow{3}{*}{$\begin{array}{l}\text { Erdmans Brook } \\
\text { Coarse Sand }\end{array}$} & & & & & & & & & & & & & & & & & & & & \\
\hline & 32.5 & 721 & 1.24 & 0.59 & 14.5 & 0.78 & 0.56 & 0.84 & 0.18 & 1.63 & 0.25 & & 0.13 & 0.12 & 0.04 & & & & & \\
\hline & & $(0.50)$ & $(0.06)$ & $(0.05)$ & (1.3) & (0.08) & $(0.32)$ & $(0.10)$ & $(006)$ & $(0.72)$ & $(0.22)$ & & $(0.05)$ & $(0.06)$ & $(0.03)$ & & & & & \\
\hline \multirow[t]{2}{*}{ Med. Sand } & 21.8 & 43.7 & 0.85 & 0.64 & 13.6 & 0.71 & 1.01 & 0.82 & 0.16 & 1.33 & & 0.84 & 0.13 & & & & & & & \\
\hline & & 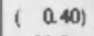 & $(0.06)$ & $(0.06)$ & $(1.5)$ & $(0.08)$ & $(0.26)$ & $(0.09)$ & $(0.06)$ & $(0.69)$ & & $(0.07)$ & $(0.05)$ & & & & & & & \\
\hline \multirow[t]{2}{*}{ Fine Sand } & 8. 3 & 21.3 & 0.42 & 0.39 & 12.0 & 0.57 & 0.51 & 0.65 & & 0.88 & & 0.42 & & & & & & & & \\
\hline & & $\left(\begin{array}{l}0.50) \\
0\end{array}\right.$ & $(0.07)$ & $(0.08)$ & (2.1) & $(0.10)$ & $(0.35)$ & $(0.12)$ & & $(0.85)$ & & $(0.08)$ & & & & & & & & \\
\hline \multirow[t]{2}{*}{ Silt } & 32.4 & 29.5 & 0.66 & 0.54 & 15.2 & 1.03 & 0.82 & 1.14 & 0.20 & 1.22 & & 0.62 & 0.33 & 0.15 & & 83.1 & & & & \\
\hline & & $\left(\begin{array}{l}0.40) \\
(1)\end{array}\right.$ & $(0.06)$ & $(0.06)$ & (1.8) & $(0.08)$ & $(0.27)$ & $(0.10)$ & $(0.06)$ & $(0.74)$ & & $(0.07)$ & $(0.11)$ & $(0.06)$ & & (52.5) & & & & \\
\hline \multirow[t]{2}{*}{ Clay } & 5.1 & 1120 & 2.58 & 1.61 & 35.7 & 1.30 & 1.81 & 2.07 & 0.20 & 1.94 & & 2.25 & & 0.09 & & & & & & \\
\hline & & $\left(\begin{array}{ll}(1.0\end{array}\right)$ & $(0.14)$ & $(0.15)$ & $(3.0)$ & $(0.17)$ & ( 0.61) & $(0.20)$ & $(0.11)$ & ( 0.91 ) & & $(0.17)$ & & (0.05) & & & & & & \\
\hline \multicolumn{21}{|l|}{$B C-1$} \\
\hline \multirow[t]{2}{*}{ Sand } & 98.4 & & 0.05 & & 11.7 & 0.61 & 0.73 & 0.67 & 0.10 & 0.86 & & & & & & & 0.19 & & & \\
\hline & & & $(0.02)$ & & $(1.4)$ & ( 0.05$)$ & $(0.14)$ & $(0.07)$ & $(0.04)$ & $(0.49)$ & & & & & & & $(0.08)$ & & & \\
\hline \multirow[t]{2}{*}{ Silt } & 1.5 & 0.10 & 0.04 & & 11.9 & 0.97 & 0.88 & 0.97 & 1.10 & 1.48 & & & & & & & & & & \\
\hline & & $\left(\begin{array}{ll}( & 0.04\end{array}\right)$ & $(0.03)$ & & $(1.4)$ & $\{0.06\}$ & $(0.14)$ & $(0.07)$ & $(0.04)$ & $(0.47)$ & & & & & & & & & & \\
\hline Clay & 0.09 & & & & $\begin{array}{l}59.3 \\
(34.9)\end{array}$ & & $\begin{array}{l}4.17 \\
\text { (3.61) }\end{array}$ & $\begin{array}{r}3.05 \\
(1.61)\end{array}$ & $\begin{array}{r}202 \\
(1.05)\end{array}$ & & & & & & & & & & & \\
\hline \multicolumn{21}{|l|}{$B C-4$} \\
\hline \multirow[t]{2}{*}{ Sand } & 95.8 & 11.2 & 0.21 & 0.14 & 10.6 & 0.45 & 0.31 & 0.48 & 0.07 & 0.57 & & & & 0.08 & & & & & & \\
\hline & & $\begin{array}{ll}1 & 0.20)\end{array}$ & $(0.03)$ & (0.03) & (1.14) & $(0.05)$ & $(0.17)$ & $(0.06)$ & $\left\{\begin{array}{l}(0.3\} \\
\}\end{array}\right.$ & $\{0.32\}$ & & & & $(0.04)$ & & & & & & \\
\hline \multirow[t]{2}{*}{ Silt } & 4.0 & 15.2 & 0.27 & 0.19 & 11.3 & 0.77 & 0.90 & 0.93 & 0.11 & 0.63 & & 0.25 & & 0.07 & 0.05 & & & & & \\
\hline & & $\left(\begin{array}{l}0.30 \\
)\end{array}\right.$ & $(0.04)$ & $(0.05)$ & $(1.30)$ & $(0.07)$ & $(0.21)$ & $\left(\begin{array}{l}(0.08) \\
\end{array}\right.$ & ( 0.04 ) & $(0.42)$ & & $\{0.07\}$ & & $(0.06)$ & $(0.02)$ & & & & & \\
\hline Clay & 0.2 & $\begin{array}{r}108.0 \\
\left(\begin{array}{c}2.81\end{array}\right)\end{array}$ & $\begin{array}{l}1.87 \\
(0.48)\end{array}$ & & $\begin{array}{l}34.7 \\
(18.0)\end{array}$ & $\begin{array}{l}2.26 \\
1.00\}\end{array}$ & $\begin{array}{l}6.17 \\
(2.54)\end{array}$ & $\mid \begin{array}{r}3.28 \\
(1.00)\end{array}$ & & & & & & & & & & & & \\
\hline \multicolumn{21}{|l|}{ CC-1 } \\
\hline \multirow[t]{2}{*}{ Sand } & 98.7 & 0.19 & & & 9.40 & 0.36 & 0.37 & \begin{tabular}{|l|l|} 
& 0.43 \\
\end{tabular} & 0.05 & & & & & & & & & & & \\
\hline & & $(0.04)$ & & & $(1.09)$ & $(0.04)$ & $(0.09)$ & $(0.04)$ & $(0.02)$ & & & & & & & & & & & \\
\hline Silt & 1.3 & 0.98 & & 0.07 & 11.5 & 0.92 & 0.96 & 0.97 & 0.15 & 1.98 & & & & 0.05 & & & 0.18 & & & \\
\hline & & $\left(\begin{array}{l}(0.09) \\
0\end{array}\right.$ & & $(0.06)$ & $(2.0)$ & $(0.00)$ & $\{0.19\}$ & $(0.09)$ & $(0.06)$ & $(0.71)$ & & & & $(0.04)$ & & & $(0.12)$ & & & \\
\hline Clay & 0.04 & 14.8 & & 0.90 & 27.7 & 1.95 & & 3.10 & 0.68 & & & & & & & & & & & \\
\hline & & $\left(\begin{array}{l}(1.7) \\
\text { ) }\end{array}\right.$ & & $(0.87)$ & (16.9) & $(1.00)$ & & $(1.00)$ & 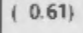 & & & & & & & & & & & \\
\hline CC-3/1 & & & & & & & & & & & & & & & & & & & & \\
\hline Sand & 79.3 & 204 & 0.05 & & 9.93 & 0.44 & 0.43 & 0.44 & 0.07 & 0.50 & & & & & & & & & & \\
\hline & & $(0.16)$ & $(0.04)$ & & $(1.67)$ & $(0.06)$ & (0.18) & $(0.07)$ & $(0.04)$ & (a 38$)$ & & & & & & & & & & \\
\hline $\begin{array}{l}\text { Silt } \\
\text { Clay }\end{array}$ & $\begin{array}{r}20.4 \\
0.4\end{array}$ & $\begin{array}{l}\text { N.A. } \\
21.8\end{array}$ & N.A. & N.A. & $\begin{array}{l}\text { N.A. } \\
33.7\end{array}$ & N.A. & N.A. & N.A. & N.A. & N.A. & N.A. & N.A. & N.A. & N.A. & N.A. & N.A. & N.A. & & & \\
\hline & 0.7 & $\left(\begin{array}{l}1.5 \\
)\end{array}\right.$ & & & $\begin{array}{r}33.7 \\
(9.7)\end{array}$ & $\begin{array}{l}1.00 \\
(0.40)\end{array}$ & & $\left(\begin{array}{l}2.20 \\
(0.53)\end{array}\right.$ & $\left(\begin{array}{l}0.33 \\
(0.26)\end{array}\right.$ & & & & & & $(0.13)$ & & & & & \\
\hline
\end{tabular}


TABLE 7. (Continued)

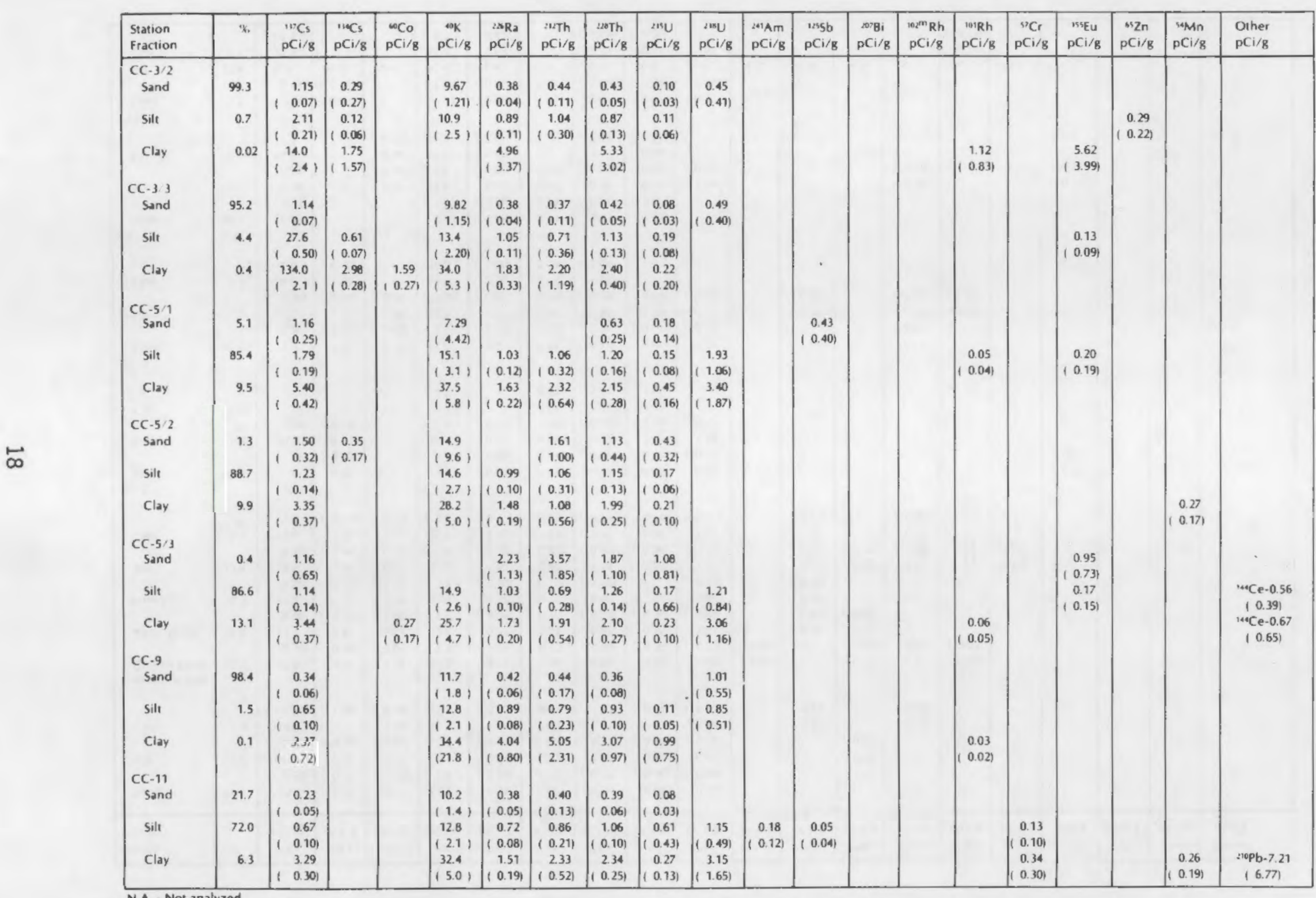

Blanks indicate a radionuclide level was below detection

( ) parentheses represent two standard deviations 
TABLE 8. Suspended Particulate Radionuclides of Gamma Emitters

\begin{tabular}{|c|c|c|c|c|c|c|c|c|c|c|c|c|c|c|c|c|c|}
\hline \multirow{3}{*}{ Location } & \multicolumn{17}{|c|}{$\mathrm{PCi} / \mathrm{g}$ in Suspended Sediment } \\
\hline & $\mathrm{Am}$ & $\mathrm{Bi}$ & Co & Cs & Cs & $\mathrm{Ce}$ & K & $\mathrm{Mn}$ & $\mathrm{Ra}$ & $\mathrm{Rh}$ & $\mathrm{Rh}$ & Th & Th & $U$ & $U$ & Zn & Eu \\
\hline & 241 & 207 & 60 & 134 & 137 & 144 & 40 & 54 & 226 & 101 & $102 \mathrm{~m}$ & 228 & 232 & 235 & 238 & 65 & 155 \\
\hline Background & & & & 0.42 & 1.46 & 3.57 & 28.2 & & 1.68 & & & 1.62 & 3.95 & & 4.76 & & 0.96 \\
\hline & & & & $(0.31)$ & $(0.50)$ & ( 1.93) & $(8.3)$ & & & & & $(0.61)$ & $(1.17)$ & & (4.85) & & $(0.76)$ \\
\hline$B C-1$ & & & & & 0.21 & & 18.2 & & 1.02 & & & 1.44 & 1.56 & 0.11 & 4.19 & 0.53 & \\
\hline & & & & & $(0.16)$ & & $(4.8)$ & & $(0.20)$ & & & $(0.25)$ & $(0.64)$ & $(0.11)$ & $(2.30)$ & $(0.37)$ & \\
\hline $\mathrm{CC}-1$ & 0.39 & & & & 0.48 & 18.8 & 19.8 & & 0.82 & 0.09 & & 1.21 & 1.11 & 0.19 & & & \\
\hline & $(0.29)$ & & & & $(0.23)$ & (13.3) & $(6.0)$ & & $(0.24)$ & $(0.04)$ & & $(0.29\}$ & $(0.57)$ & $(0.12)$ & & & \\
\hline FC-1 & & & & 0.34 & 17.4 & & 23.2 & & 0.80 & & & 1.40 & 1.31 & 0.65 & & & \\
\hline & & & & $(0.13)$ & $(0.85)$ & & $(8.3)$ & & $(0.21)$ & & & $(0.32)$ & $(0.73)$ & $(0.57)$ & & & \\
\hline$B C-4$ & & & & & 2.06 & & 20.0 & & 1.06 & & & 1.35 & 1.03 & 0.14 & 2.35 & & \\
\hline & & & & & $(0.14)$ & & $(2.6)$ & & $(0.10)$ & & & $(0.13)$ & $(0.26)$ & $(0.08)$ & $(0.96)$ & & \\
\hline CC-3/1/Top & & & 1.13 & 0.18 & 1.49 & & 8.14 & & 1.23 & & & 1.68 & 1.82 & 0.39 & & & \\
\hline & & & $(1.03)$ & $(0.15)$ & $(0.43)$ & & $(6.67)$ & & $(0.30)$ & & & $(0.58)$ & $(1.38)$ & $(0.28)$ & & & \\
\hline CC-3/1/Bottom & & & & 0.30 & 2.07 & & 28.71 & & 0.87 & & & 1.52 & 1.75 & 0.15 & & & \\
\hline & & & & $(0.21)$ & $(0.41)$ & & ( 8.98$)$ & & $(0.31)$ & & & $(0.41)$ & $(0.84)$ & $(0.05)$ & & & \\
\hline $\mathrm{CC}-3 / 2$ & & 0.162 & & & 2.25 & & 26.20 & & 1.07 & & & 1.81 & 0.59 & 0.26 & 1.95 & 0.17 & 0.36 \\
\hline & & $(0.099)$ & & & $(0.31)$ & & (6.39) & & $(.228)$ & & & $(0,31)$ & $(0.23)$ & $(0.15)$ & $(1.79)$ & $(0.105)$ & $(0.32)$ \\
\hline $\mathrm{CC}-3 / 3$ & & & & & 2.10 & & 21.40 & & 0.77 & & & 1.14 & 0.92 & 0.13 & & & \\
\hline & & & & & $(0.29)$ & & (4.83) & & $(0.13)$ & & & $(0.24)$ & $(0.34)$ & $(0.08)$ & & & \\
\hline CC $-5 / 1$ & & & & & 1.35 & & 18.43 & & 0.945 & & & 1.33 & 0.94 & 0.15 & 1.24 & & 0.14 \\
\hline & & & & & $(0.14)$ & & $(2.38)$ & & $(0.09)$ & & & $(0.12)$ & $(0.27)$ & $(0.05)$ & $(0.60)$ & & $(0.11)$ \\
\hline CC-5/2/Top & & & & & 1.19 & & 22.28 & & 0.873 & & & 1.50 & 0.79 & 0.17 & & & \\
\hline & & & & & $(0.27)$ & & $(5.86)$ & & $(0.26)$ & & & $(0.30)$ & $(0.53)$ & $(0.11)$ & & & \\
\hline CC-5/2/Mid & & & & & 1.27 & & 22.54 & & 1.20 & & & 1.50 & 1.39 & 0.22 & 1.72 & & 0.12 \\
\hline & & & & & $(0.18)$ & & $(4.40)$ & & $(0.165)$ & & & $(0.20)$ & $(0.45)$ & $(0.09)$ & $(1.09)$ & & $(0.11)$ \\
\hline CC-5/2/Bottom & & & & & 1.12 & & 21.02 & & 0.939 & & & 1.40 & 1.21 & 0.15 & 0.41 & & \\
\hline & & & & & $(0.18)$ & & $(2.60)$ & & $(0.134)$ & & & $(0.17)$ & $(0.38)$ & $(0.07)$ & $(0.22)$ & & \\
\hline $\mathrm{CC}-5 / 3$ & & & & & 1.30 & & 18.62 & & 1.00 & & & 1.26 & 1.04 & 0.15 & & & \\
\hline & & & & & $(0.27)$ & & $(4.87)$ & & $(0.17)$ & & & $(0.27)$ & $(0.52)$ & $(0.09)$ & & & \\
\hline CC-9 & & & & & 2.04 & & 25.45 & 0.17 & 0.910 & 0.07 & & 1.74 & 1.38 & 0.22 & 2.12 & & \\
\hline & & & & & $(0.25)$ & & $(4.52)$ & $(0.15)$ & $(0.16)$ & $(0.05)$ & & $(0.22)$ & $(0.50)$ & $(0.12)$ & $(1.41)$ & & \\
\hline CC-11/Top & & & & & 1.61 & & 21.71 & & 1.16 & & 0.093 & 1.17 & 1.30 & 0.18 & & & \\
\hline & & & & & $(0.27)$ & & ( 5.15$)$ & 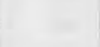 & $(0.249)$ & & $(0.06)$ & $(0.26)$ & $(0.67)$ & $(0.09)$ & & & \\
\hline CC-11/Bottom & & & & & 1.93 & & 19.36 & 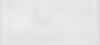 & 1.02 & & & 1.58 & 1.54 & 0.17 & 1.00 & & 0.22 \\
\hline & & & & & $(0.25)$ & & (4.93) & & $(0.13)$ & & & $(0.25)$ & $(0.52)$ & $(0.08)$ & $(0.72)$ & & $(0.14)$ \\
\hline
\end{tabular}

Blanks indicate a radionuclide level was below detection Parentheses () represents two standard deviations 
TABLE 9. Weighted Average of Concentrations of Particulate Radionuclides of Gamma Emitters in River Bed

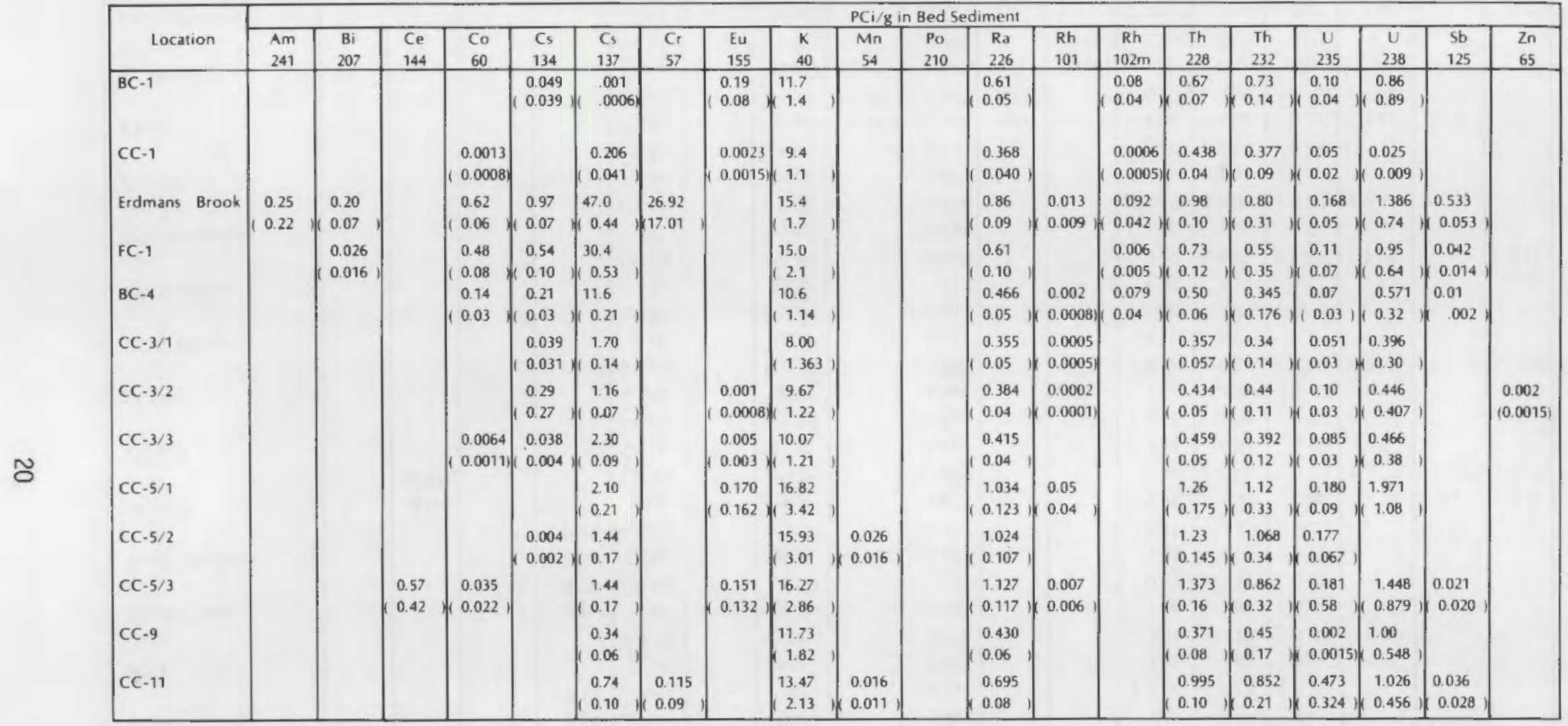

No sand data for $B C-1\left(C_{5} 137\right)$

No sand, sile data for CC-5/2, CC-11, (Mn54)

No sand data for BC-4, CC-3/1, 3/2, 5/3, 9, Rh101

Blanks indicate a radionuclide level was below detection

Parentheses ( ) represents two standard deviations 


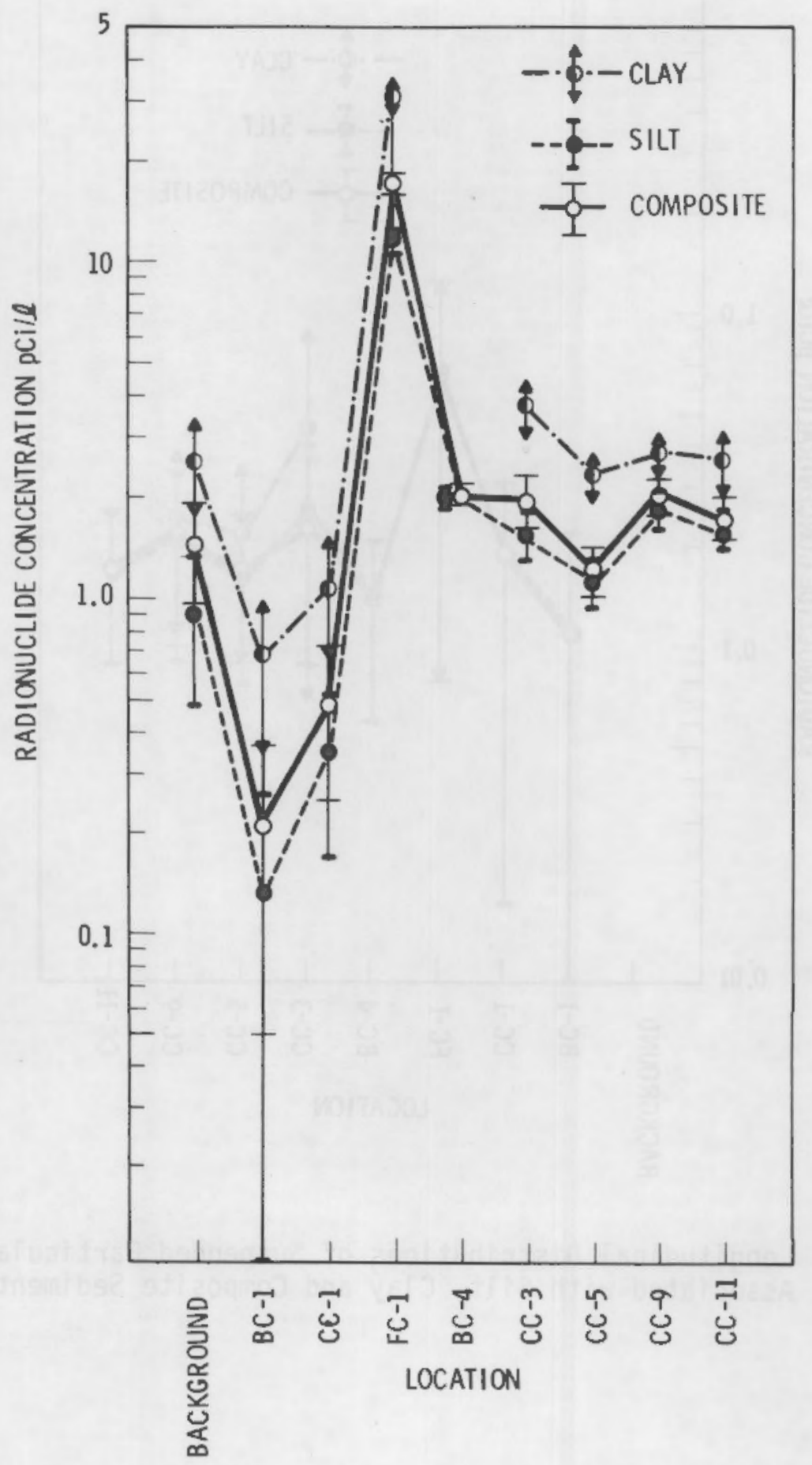

FIGURE 3. Longitudinal Distributions of Suspended Particulate ${ }^{137} \mathrm{CS}$ Associated with Silt, Clay and Composite Sediment 


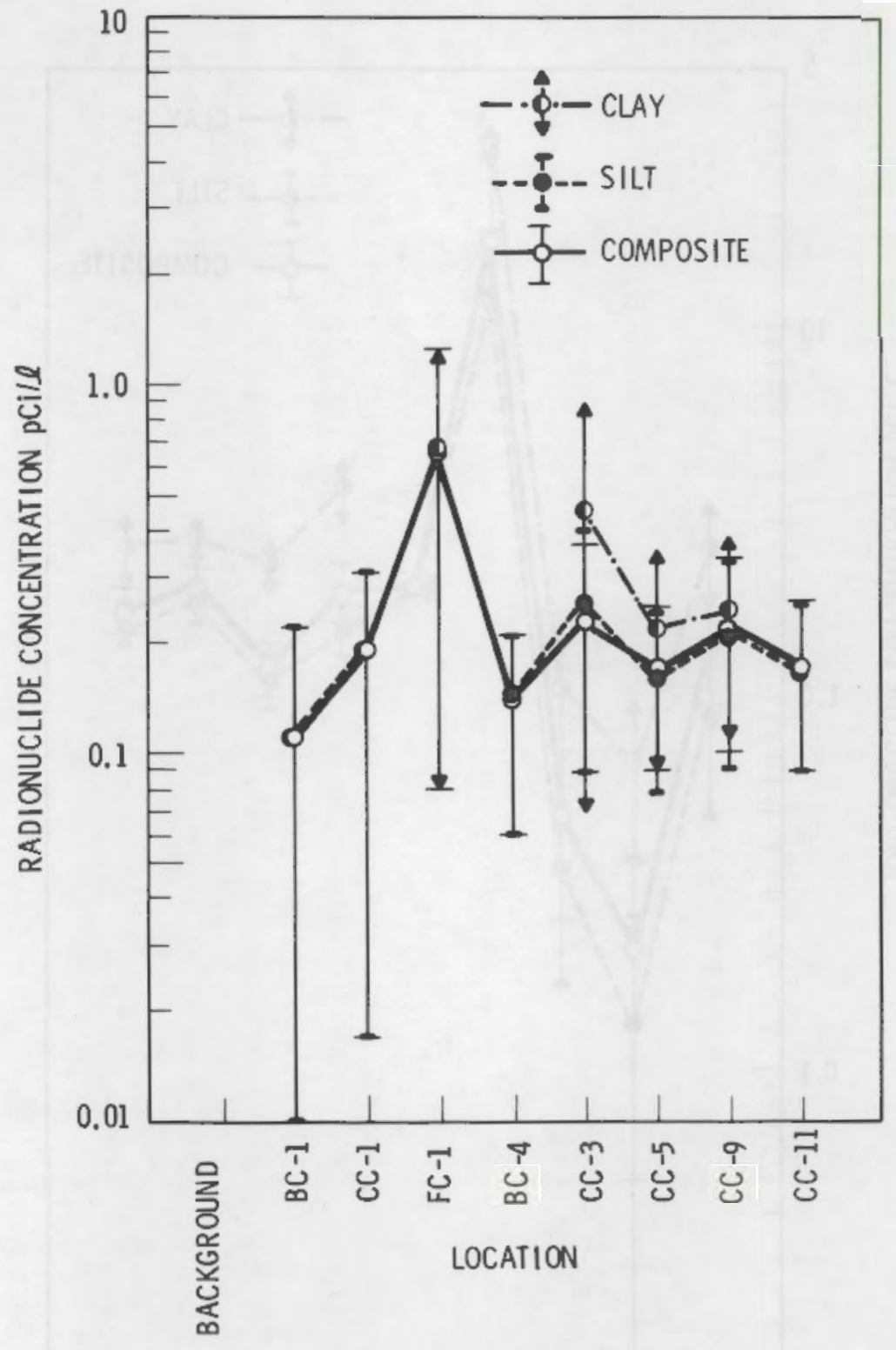

FIGURE 4. Longitudinal Distributions of Suspended Particulate $235 \mathrm{U}$ Associated with Silt, Clay and Composite Sediment 


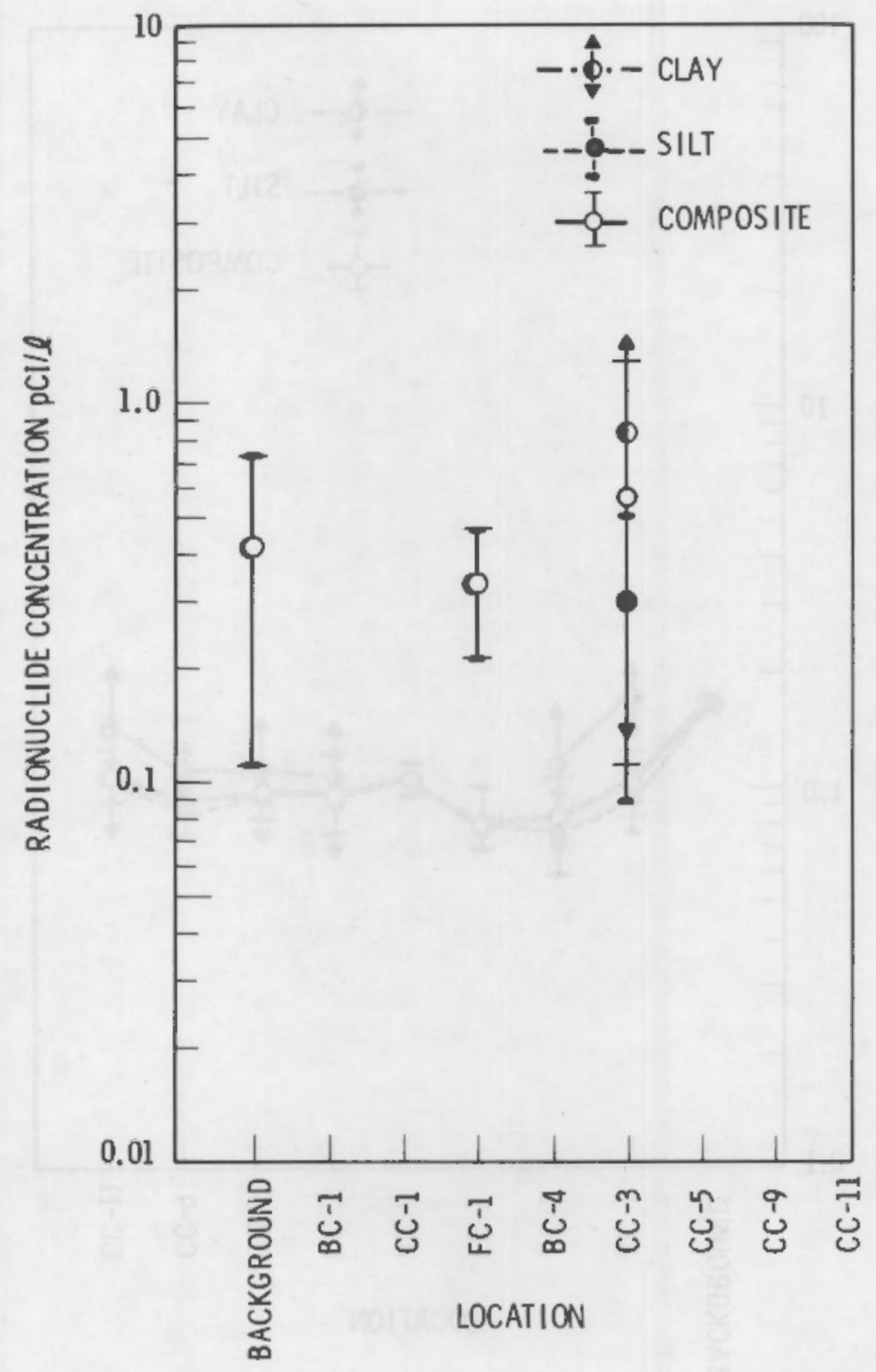

FIGURE 5. Longitudinal Distributions of Suspended Particulate ${ }^{134} \mathrm{Cs}$ Associated with Silt, Clay and Composite Sediment 


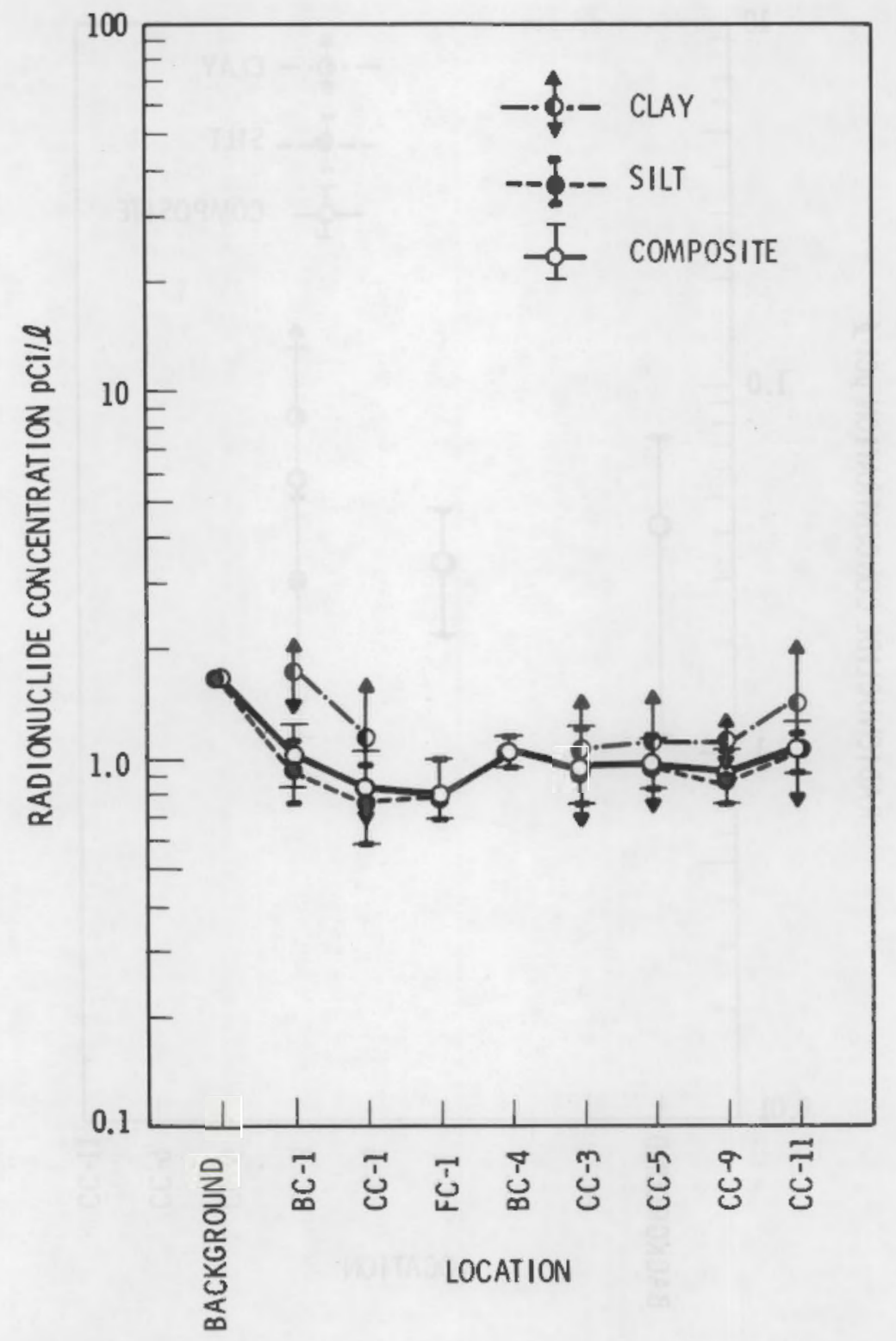

FIGURE 6. Longitudinal Distributions of Suspended Particulate 226Ra Associated with Silt, Clay and Composite Sediment 


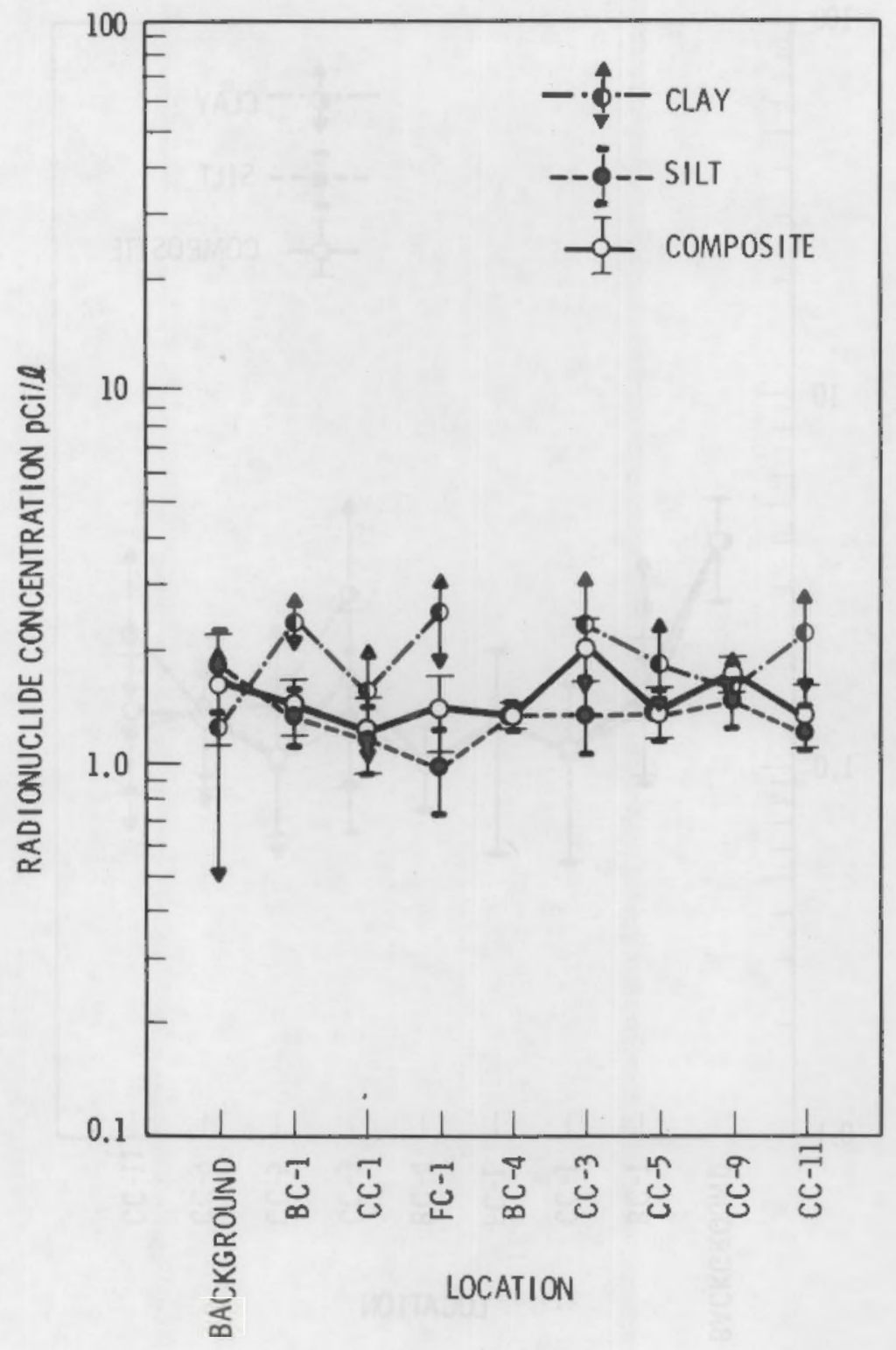

FIGURE 7. Longitudinal Distributions of Suspended Particulate 228Th Associated with Silt, Clay and Composite Sediment 


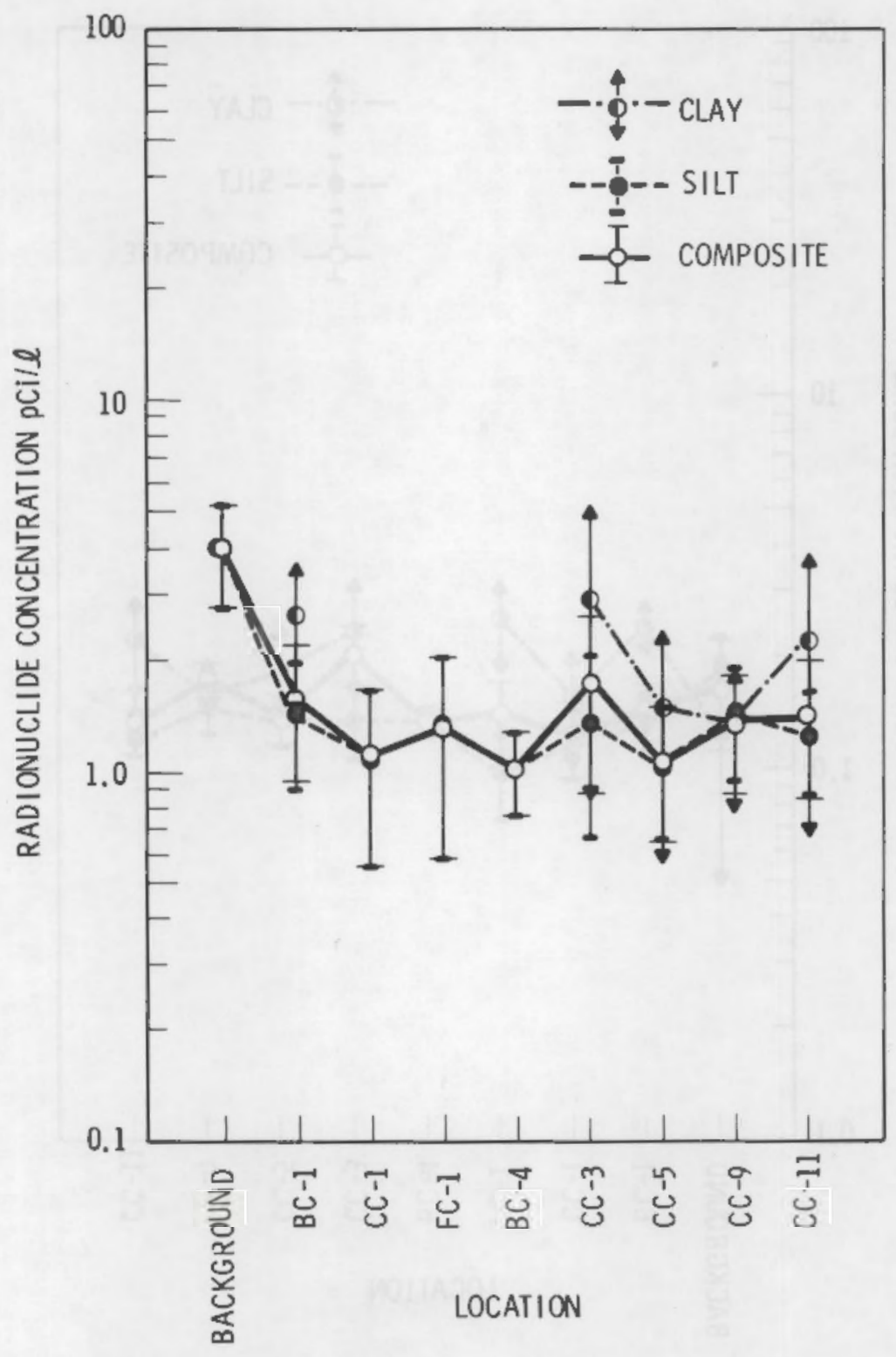

FIGURE 8. Longitudinal Distributions of Suspended Particulate ${ }^{232}$ Th Associated with Silt, Clay and Composite Sediment 


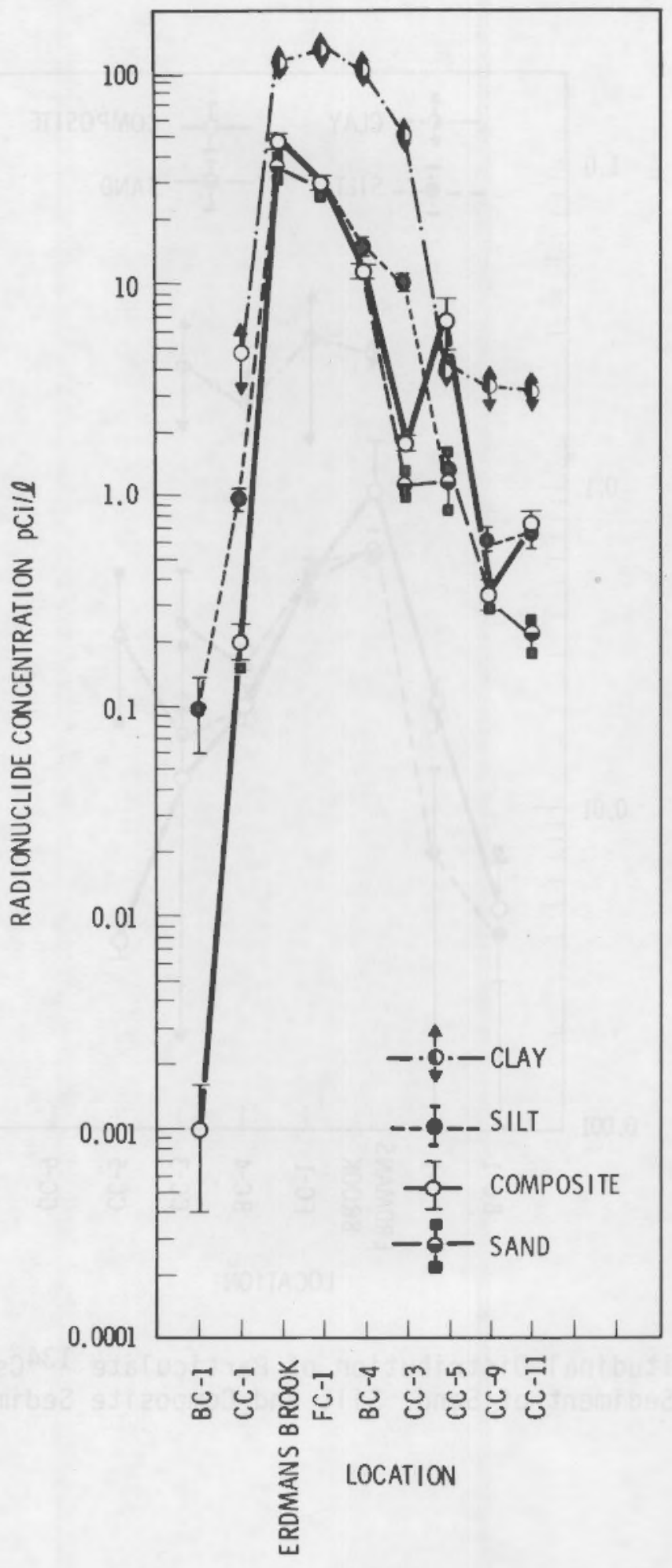

FIGURE 9. Longitudinal Distribution of Particulate $137 \mathrm{Cs}$ Associated with Bed Sediment of Sand, Silt, Clay and Composite Sediment 


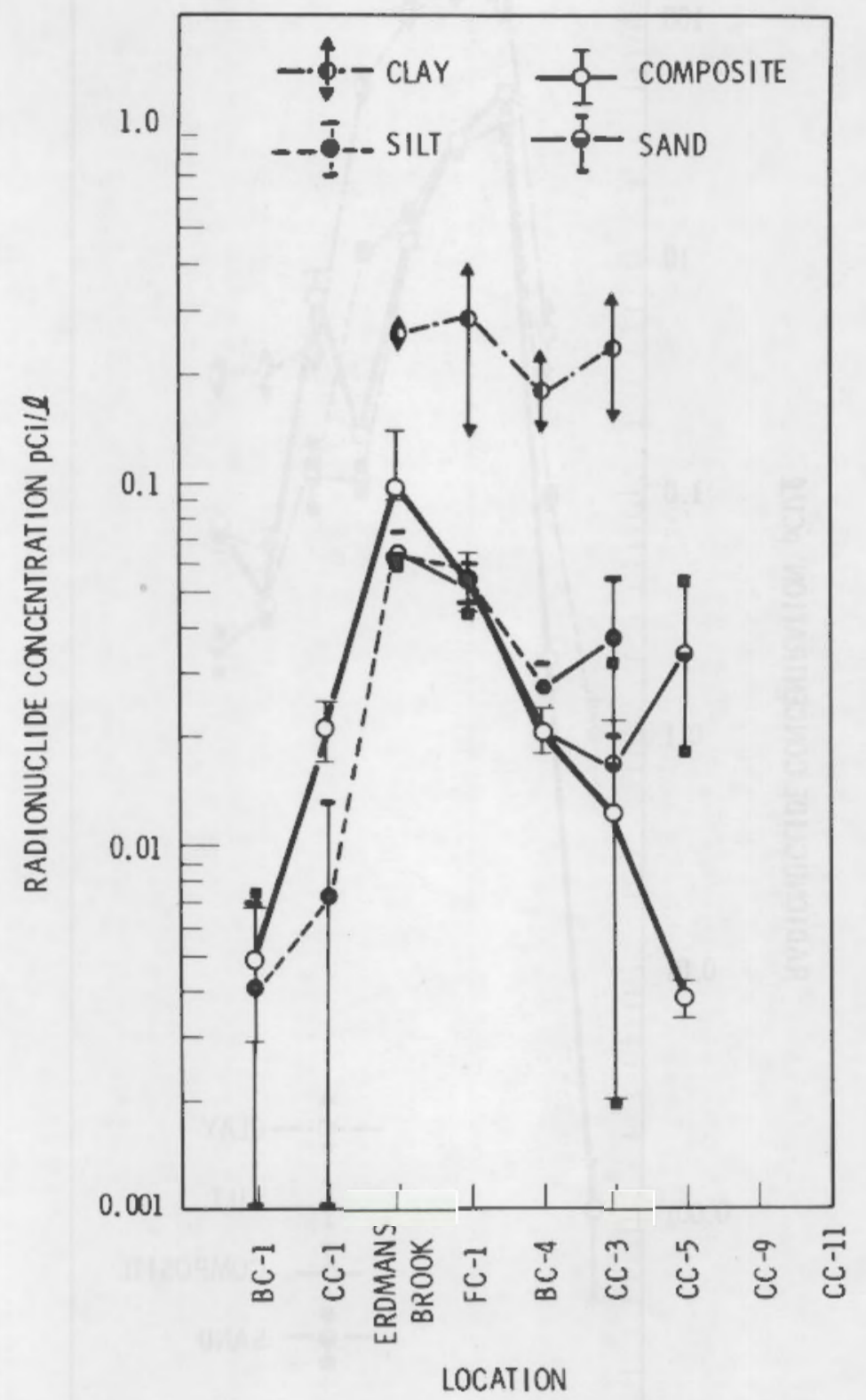

FIGURE 10. Longitudinal Distribution of Particulate ${ }^{134} \mathrm{Cs}$ Associated with Bed Sediment of Sand, Silt and Composite Sediment 


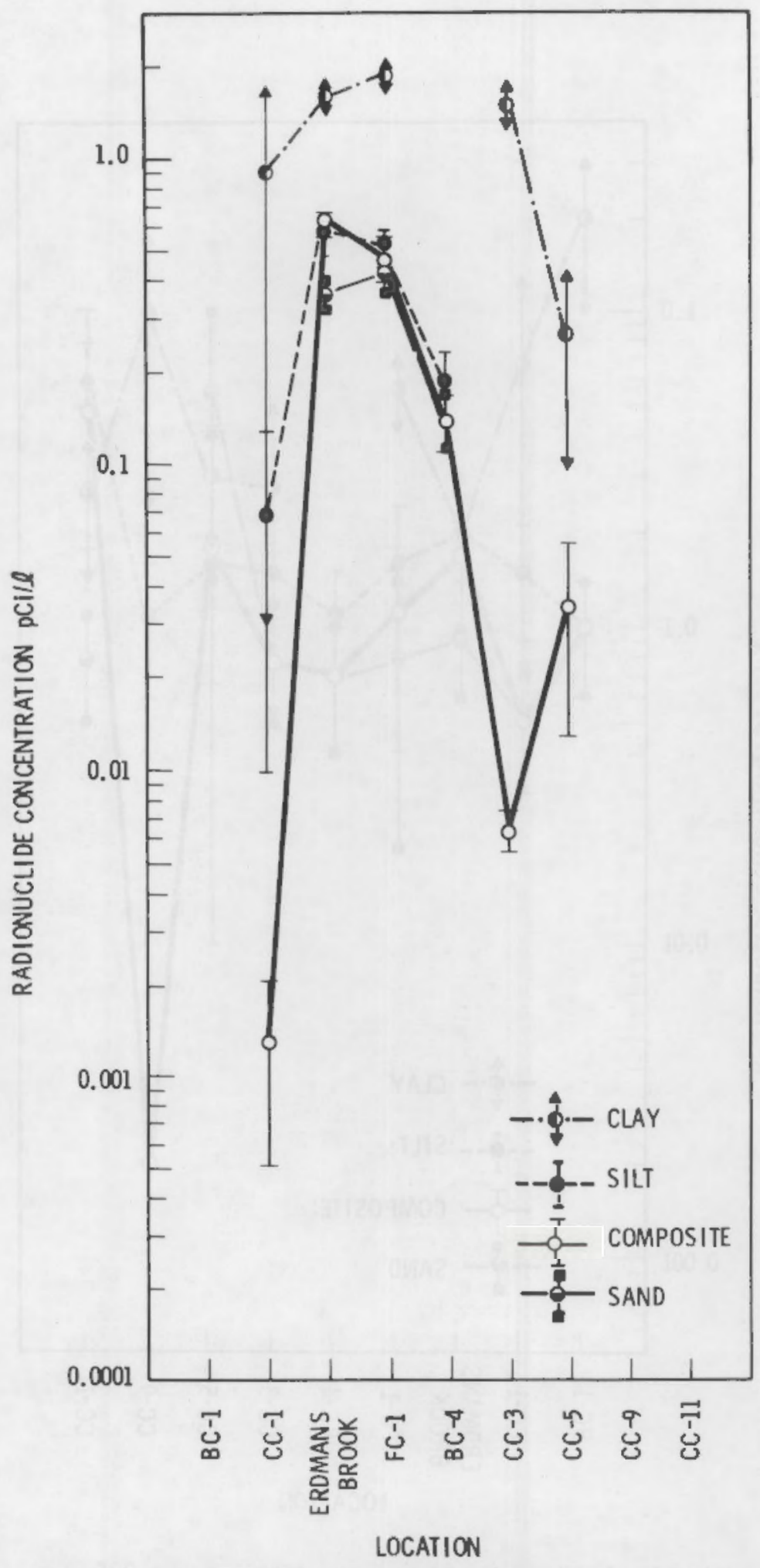

FIGURE 11. Longitudinal Distribution of Particulate ${ }^{60} \mathrm{Co}$ Associated with Bed Sediment of Sand, Silt, Clay and Composite Sediment 


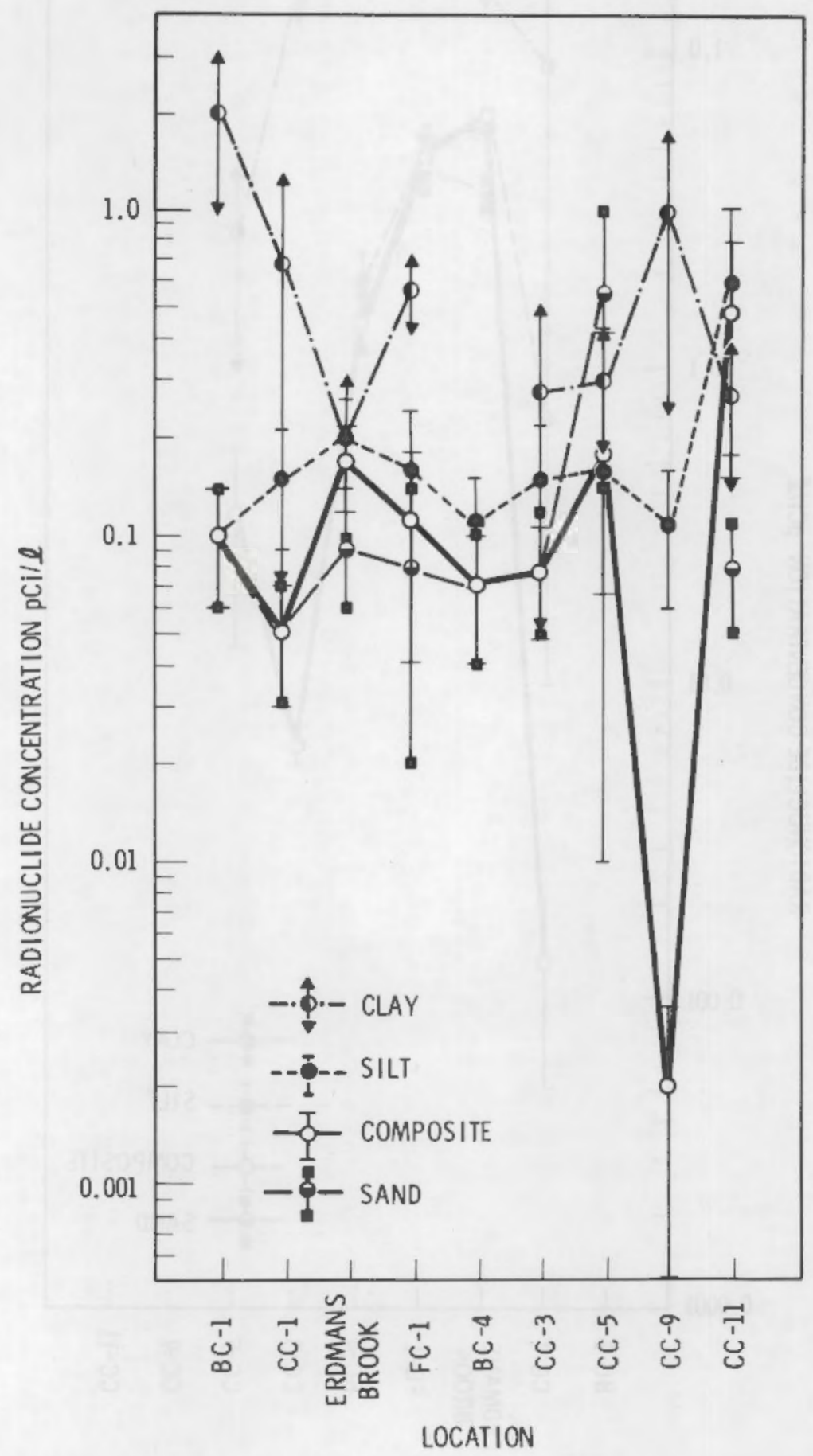

FIGURE 12. Longitudinal Distribution of Particulate 235U Associated with Bed Sediment of Sand, Silt, Clay and Composite Sediment 


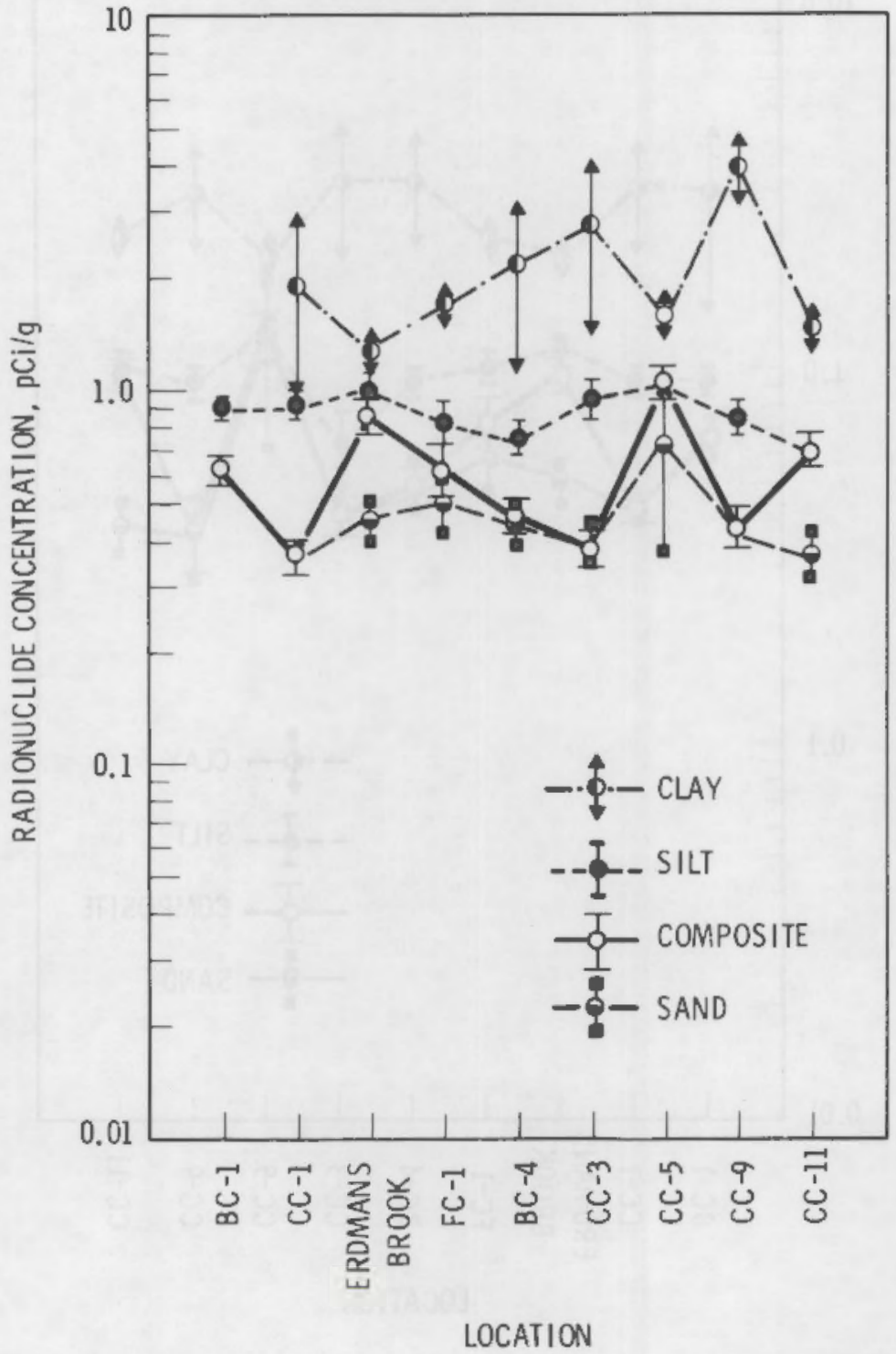

FIGURE 13. Longitudinal Distribution of Particulate 226Ra Associated with Bed Sediment of Sand, Silt, Clay and Composite Sediment 


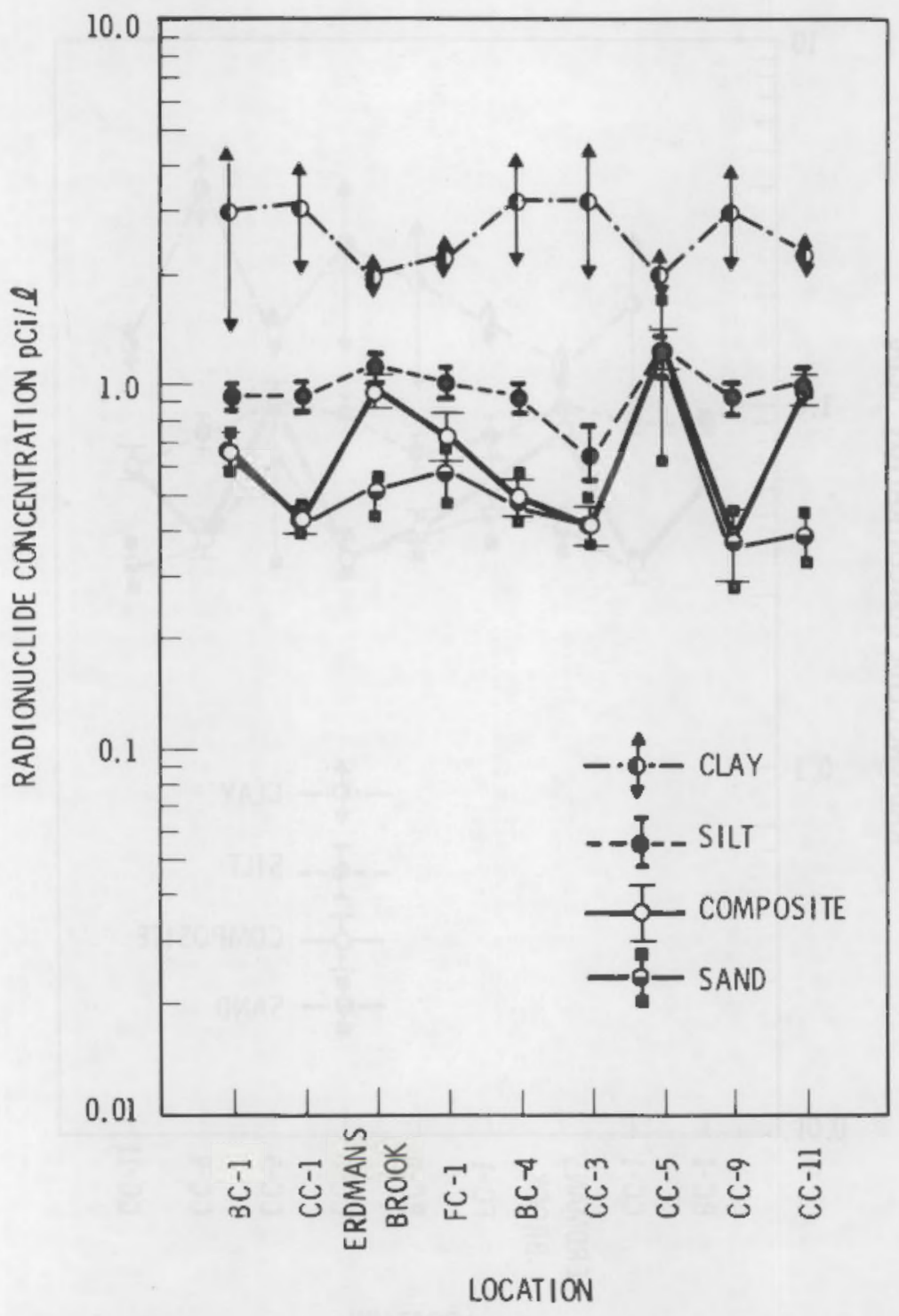

FIGURE 14. Longitudinal Distribution of Particulate ${ }^{228}$ Th Associated with Bed Sediment of Sand, Silt, Clay and Composite Sediment 


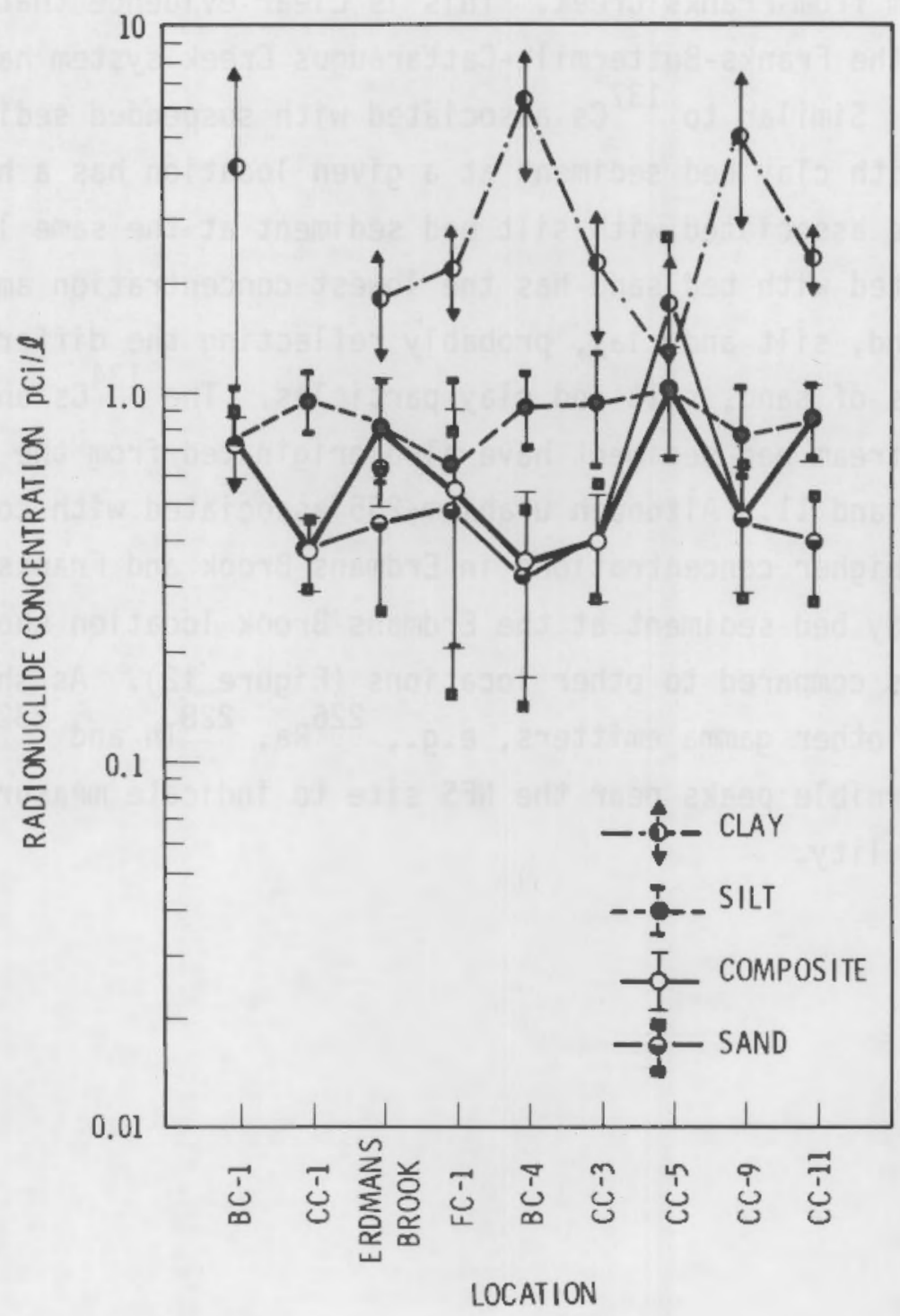

FIGURE 15. Longitudinal Distributions of Particulate ${ }^{232}$ Th Associated with Bed Sediment of Sand, Silt, Clay and Composite Sediment 
we 11 as the composite bed sediment. Cesium-137 concentrations in the riverbed decrease downstream from Franks Creek. This is clear evidence that most of ${ }^{137}$ Cs existing in the Franks-Buttermilk-Cattaraugus Creek system has come from the NFS site. Similar to ${ }^{137} \mathrm{Cs}$ associated with suspended sediment, ${ }^{137}$ Cs associated with clay bed sediment at a given location has a higher concentration than one associated with silt bed sediment at the same location. Cesium-137 associated with bed sand has the lowest concentration among those associated with sand, silt and clay, probably reflecting the differences in exchange capacities of sand, silt and clay particles. The ${ }^{134} C_{s}$ and ${ }^{60} C_{0}$ remaining in the stream bed sediment have also originated from the NFS site, as shown in Figure 10 and 11. Although uranium-235 associated with composite bed sediment also has higher concentrations in Erdmans Brook and Franks Creek, ${ }^{235} \mathrm{U}$ associated with clay bed sediment at the Erdmans Brook location shows the smallest concentrations compared to other locations (Figure 12). As shown in Figures 12 through 15 other gamma emitters, e.g., ${ }^{226} \mathrm{Ra},{ }^{228} \mathrm{Th}$ and ${ }^{232} \mathrm{Th}$, do not have clearly discernible peaks near the NFS site to indicate measurable input from the waste facility. 


\section{PHASE 3 SAMPLING PROGRAM}

During FY-1979, a hydrologic analysis for Phase 3 was performed. However, no radiological analys is for Phase 3 has been conducted yet.

HYDROLOGIC DATA COLLECTION

\section{Purpose of Monitoring Effort}

The purpose of the hydrological monitoring task is to provide input data of the actual flow conditions during the sampling period for unsteady state flow modeling. The results of the unsteady state flow computations will provide hydraulic input data for the sediment-contaminant model SERATRA. The collected hydrologic data include river stage readings versus time at temporary gage locations, vertical velocity measurements, channel cross-section surveys, and water surface slopes.

Certain sediment data are required as input to SERATRA and were collected simultaneously with the gage readings. These data are wash load concentrations (clay and silt fractions) and channel bed material samples (sand fractions). Wash load concentrations versus time are required at all primary channel network and tributary inflow points. Bed material samples are necessary for the determination of sand size fraction distribution.

The primary stream system under study consists of a length of Buttermilk Creek that extends from the mouth of Franks Creek at the NFS facilities to its confluence with Cattaraugas Creek which is about 12,500 feet of channel. The length of Cattaraugas extends 39 miles downstream to its outlet at Lake Erie. This is the assumed pathway of radionuclide migration for surface waters. In order to simplify model verification, a short reach of Buttermilk and Cattaraugas Creek system about 10 miles long was selected for detailed monitoring. The reach extends from just above the confluence with Buttermilk Creek to just upstream of Connoisarauley Creek. This reduces the number of tributaries that require monitoring to two which are Spring Brook and Spooner Creek.

Hydrographs of water discharge versus time are required at all significant inflow points of the selected reaches of Cattaraugas and Buttermilk Creeks. 
The channel geometry will be determined from the cross-sectional surveys and the channel slope measured from USGS topographic maps. Using these data the unsteady flow model will generate water depths and average cross-sectional velocities at specified points along the channel length for input into SERATRA. The wash load sediment concentration versus time and bed material size distribution data are not required for the unsteady flow modeling but will be input data for SERATRA.

\section{CATTARAUGAS CREEK WATERSHED}

\section{Location}

Cattaraugus Creek flows in a westerly direction through the Zoar Valley and empties into Lake Erie about $27 \mathrm{miles}$ southwest of Buffalo, New York. The principal community on Cattaraugas Creek is Gowanda, New York which is located about 19 stream miles upstream from Lake Erie. The confluence of Buttermilk Creek is 20 miles further upstream from Gowanda. The total drainage area of the watershed is 564 square miles.

The watershed area upstream of Buttermilk Creek includes 218 square miles and above Gowanda about 432 square miles.

\section{Geomorphology}

The Cattaraugas Creek watershed in Western New York lies within the Allegheny Plateau physiographic province. The pre-glacial erosional surface of the watershed was dissected upland with deeply incised valleys. Many of the valleys have been buried by a considerable volume of glacial deposits with the result that much of the present drainage is post-glacial and bedrock valleys which have depth and direction varying from the present valleys.

The present course of Buttermilk Creek is incised into glacial deposits and recent alluvium which fill a deep pre-glacial bedrock gorge. The channel pattern in the vicinity of its confluence with Franks Creek is that of a braided stream where at low flows there will be multiple channels.

At low flows Buttermi lk Creek discharge follows a meandering underfit channel pattern among the alluvial islands within its narrow flood plain. At 
many locations the bankline is poorly defined and unstable. Evidence of very recent bank caving exists at some locations. Two primary causes generally assumed to be responsible for a braided condition are (1) a sediment load which exceeds the transport capacity of the stream, and (2) a steep channel slope, which tends to produce a wide shallow channel where bars and islands easily form.

At about the mid-point of the reach between the Franks Creek outlet and the confluence with Cattaraugas Creek the channel begins to establish a meandering plan geometry. Bendway development gives an S-shaped appearance which increases in size as the confluence with Cattaraugas Creek is approached. Meandering is a trading process of erosion and deposition. Material is eroded from the concave banklines of bendways and deposited on point bars (convex banklines) over a period of time. For easily erodible banks this process leads to a noticeable migration of the bendways over a period of years.

Cattaraugas Creek from the mouth of Buttermilk Creek to its outlet at Lake Erie has a meandering plan view geometry. There are reaches where alluvial islands and bars are present which cause a braided appearance at low flows. For the most part these multi-channeled reaches appear to have remained stable where the islands and bars tend to remain in their general location. Some islands lie adjacent to a bankline and have well-established vegetation. Many of the point bars are clear of established vegetation indicating prolonged inundation during the high water season or growth of the alluvial bar area. Both of these phenomena usually work in concert which is probably the case for Cattaraugas Creek.

Near Lake Erie the Cattaraugas Creek flood plain is much wider and terraces are prevalent. Numerous meander scrolls are evident in the cleared agricultural lands and can be determined by the difference in soil type and moisture content. Other cutoff bendways of more recent origin are in the form of oxbow lakes which may receive flow from the creek during spring floods. It is difficult to determine if the meandering process is very active without a sequence of aerial photos and mapping covering a sufficient time period, however, the presence of erosion control structures at a bridge near Gowanda indicates meandering may still be active enough to introduce significant quantities of sediment into the streamflow. 
Hydrology

The Nuclear Fuels Service Center is located within an area that normally receives enough monthly precipitation to provide surplus water runoff throughout the year. Small quantitites of water that are withdrawn from the groundwater by farm, public, and private wells is replenished through natural percolation. Therefore, the natural water supply is more than adequate to supply the needs of the center and area. The water supply for the center is provided by surface runoff collected in two lakes in the southern portion of the center. These two lakes periodically release controlled water discharges to Buttermilk Creek at two separate inflow points about one-half mile apart and about two miles upstream from the Franks Creek confluence. The releases from these lakes superimpose a small wave disturbance on the stage hydrograph for time periods of 2 to 3 hours. A major portion of the water collected within the center will be returned to the drainage network and enter Lake Erie by way of Cattaraugus Creek. The extreme flow events for Buttermilk Creek are of short duration of hours or a few days. A report by Dana et al. (1979) discusses the USGS gage records on Buttermilk Creek from 1968 to 1973. They summarized the flow hydrograph characteristics for Buttermilk Creek as follows:

\begin{abstract}
"A hydrograph of daily discharge for water year 1962 is very "spikey" with high discharge flow events lasting only a day or two. Base-flow occurs from early summer to mid-fall and is approximately $0.3 \mathrm{~m}^{3} / \mathrm{sec}$ or less. The fall and winter peaks represent discrete rainstorm or thaw events. Spring runoff from snow melt is punctuated by rainfall events. The mean monthly discharge is much less (maximum $=2.5 \mathrm{~m}^{3} / \mathrm{sec}$ in May) than the summation of daily discharge that includes a rainfall peak $\left(14.5 \mathrm{~m}^{3} / \mathrm{sec}\right.$, max. $) . "$
\end{abstract}

The high discharge events are much higher than the mean daily flow which indicates that the high discharge events are on the order of several hours in duration. The highest discharge recorded for the period of record is $110.65 \mathrm{~m}^{3} / \mathrm{sec}$ or 3896.5 cfs (Dana et al. 1979).

The only one gaging station on Cattaraugus Creek is located at Gowanda, New York. The watershed area upstream of the gage is 432 square miles. Annua 1 peak discharge records received from the USGS Water Resources Division, Albany, 
New York, indicate that the maximum peak dishcarge of 34,600 cfs occurred on March 7, 1956 for the period of record from 1911 to 1975. The high discharges normally occur during the spring season from snowmelt coupled with rainfall.

\section{HYDROLOGIC DATA COLLECTION}

The routing of water and sediment through the Buttermilk-Cattaraugus Creek system will require monitoring the water discharge and suspended sediment concentrations at all significant inflow points. Because of the size (564 square miles) and complexity, including 16 significant tributaries from Buttermilk Creek to Lake Erie, a sub-basin area of the watershed in the immediate vicinity of NFS was selected for "more detailed" hydrologic monitoring. The area includes a 12,500 ft reach of Buttermilk Creek from just upstream of Franks Creek to its confluence with Cattaraugus Creek. The reach of Cattaraugus Creek is about 8 streamlength miles and begins at Bigelow Bridge upstream of the Buttermilk Creek confluence and extends downstream past Springville Dam to a point about $800 \mathrm{ft}$ below Frye Bridge. A map of the study area and gage locations is shown in Figure 16. Two tributaries, Spooner Creek and Spring Brook, have significant drainage areas and are included as inflow points for water and sediment. Springville Dam and reservoir are located about 2.5 miles downstream from the mouth of Buttermilk Creek and act as an intermediate control section. The reservoir serves only as pondage for the small hydroelectric plant at the dam but does trap large quantities of sediment. Flow depth over the spillway was monitored and total flow was measured at a section about $1500 \mathrm{ft}$ downstream of the dam. The difference between the flow over the spillway and the total discharge measured downstream will provide an estimate of the water passing through the turbines.

An automatic water stage recorder has been established by the New York State Geological Survey at Thomas Corners Bridge over Buttermilk Creek. This gage provided continuous stage and time data for the monitoring period and serves as a check on upstream gage readings. Periodic surges of flow occur on Buttermilk Creek due to controlled reservoir releases upstream from the NFS ponds and last for about 2 to $3 \mathrm{hr}$. Because of the difficulty of minute by minute monitoring of the upstream inflow point on Buttermilk Creek by field 


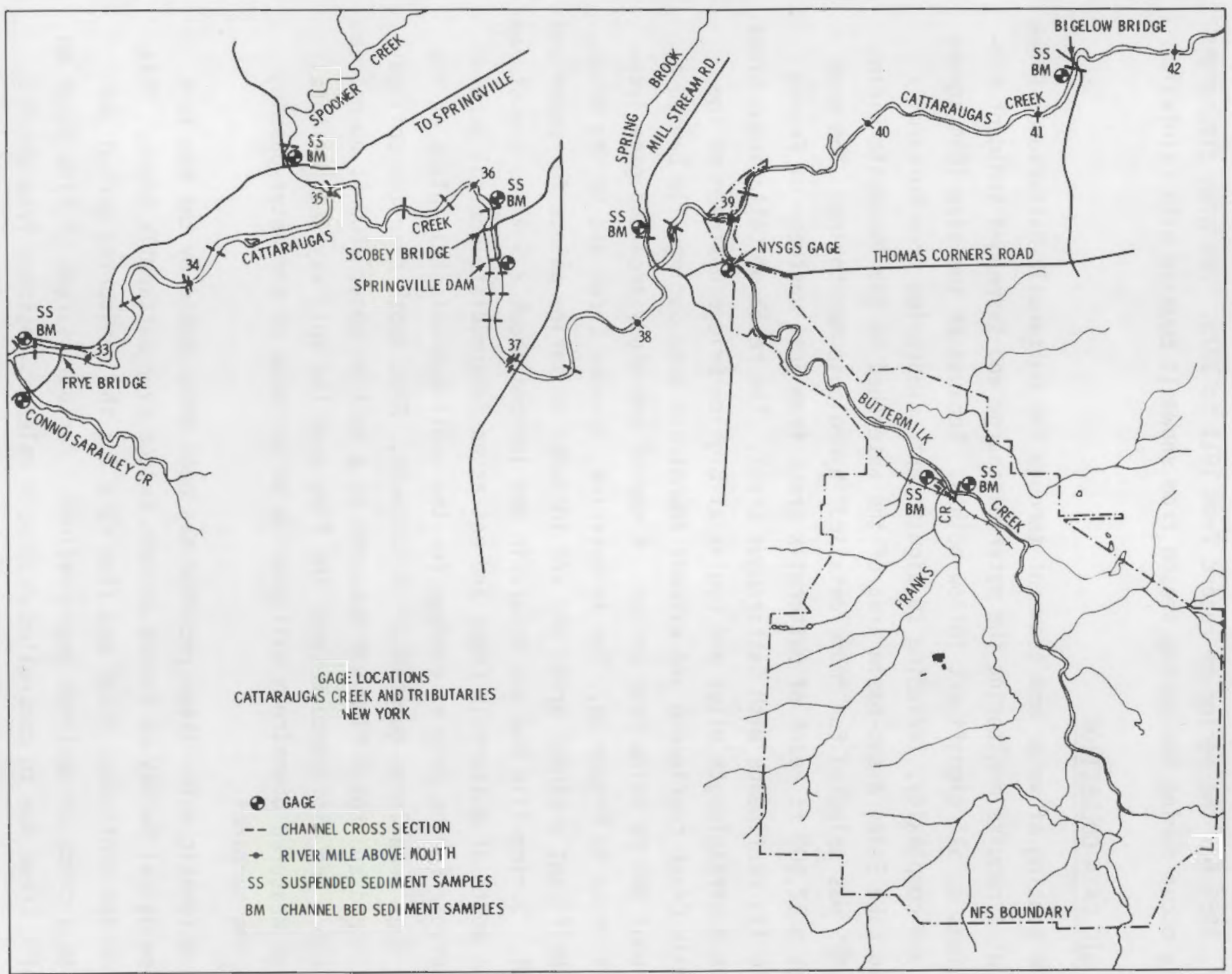

FIGURE 16. Gage Locations of Cattaraugas Creek and Tributaries, New York 
personnel, the continuous record of the Thomas Corners Bridge gage was used to insure all surges were accounted for. During the monitoring period only one surge occurred and gage readings taken at the upstream inflow point corresponds very closely with those at Thomas Corners Bridge. An instream discharge measurement was also obtained at the peak of the surge.

Suspended sediment samples are required at all inflow points on Cattaraugus and Buttermilk Creeks. Samples were also taken immediately below the dam and at the outflow point below Frye Bridge as a check on the amount of sediment being transported through the system. Bed material samples are required at these locations to determine a size distribution of the sand available for transport. This information together with the water discharge will be used to compute channel bed material transport rates.

\section{Stream Gage Network}

\section{Establishment of Gages}

The staff gages were fabricated in the field using $3 / 4$ in. galvanized pipe in lengths of $4 \mathrm{ft}$. One inch wide masking tape was used to outline 1 in. divisions with black and red spray paint as shown in Figure 17. The painted pipe sections were driven into the stream bed about $2 \mathrm{ft}$ and tied back with $1 / 8 \mathrm{in}$. cable or nylon rope for stability.

\section{Monitoring of Gages}

Beginning at 0730 on April 26, 1979 the reading of all gages in the study area commenced. The readings were taken by field personnel including the gage at Connoisarauley Creek which is very near the Frye Bridge gaging station. The auxiliary gage at South Branch Cattaraugus Creek proved to be too far downstream to effectively monitor, therefore, only two readings area available for that location. The gage readings are tabulated in Tables 10 through 17 for all monitored gages.

\section{Water Discharge Measurements}

Velocity measurements at specified intervals across the cross-section are required in order to determine the water discharge for the range of water 


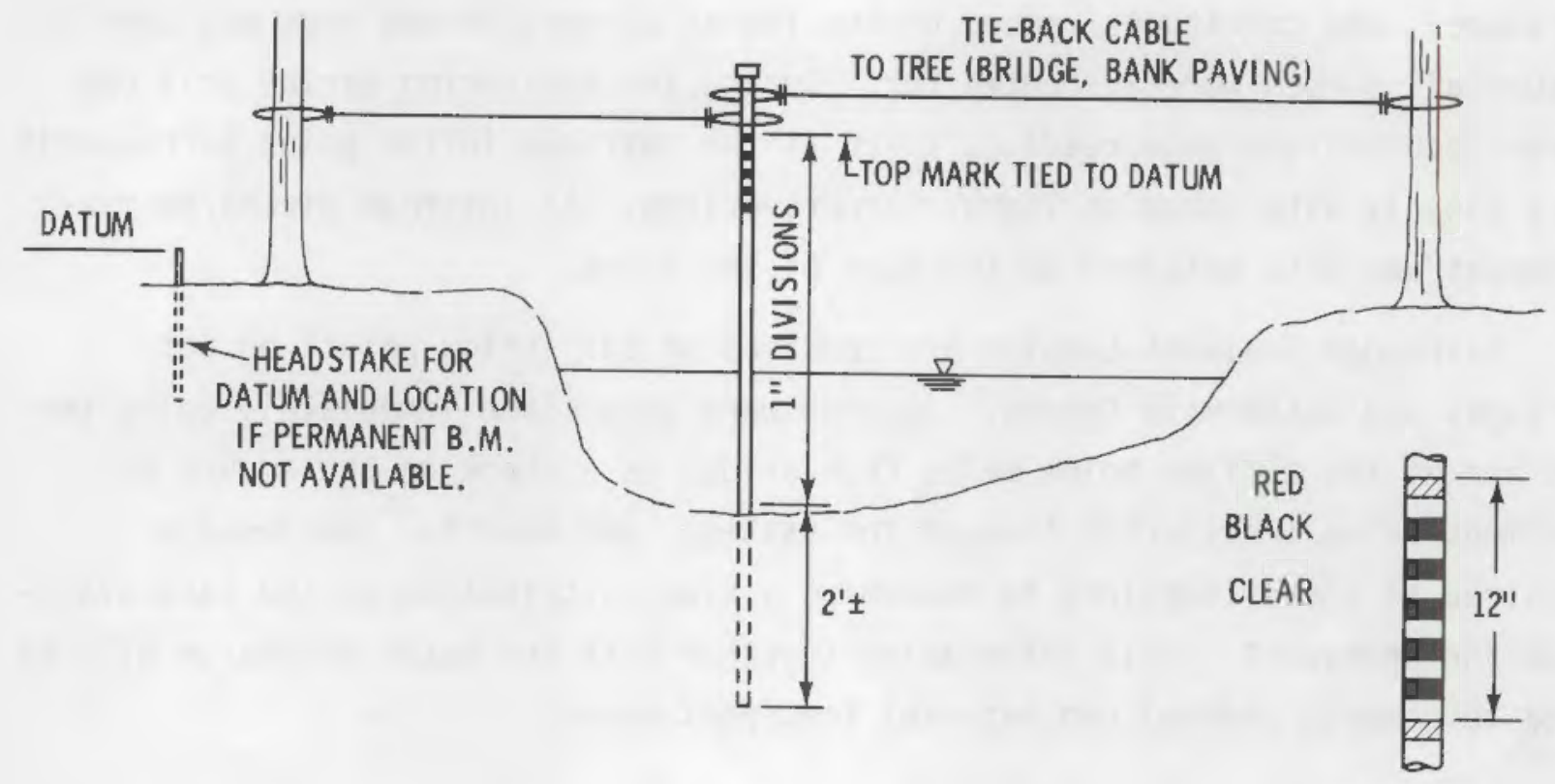

GAGE DETAIL

FIGURE 17. Typical Staff Gage Installation for Recording Changes in Water Surface Elevation

surface elevations during the monitoring period. The velocity measurements together with the cross-sectional area and water surface slope will determine the water discharge and channel roughness. These data would then be used to develop discharge hydrographs for each gage location. The discharge hydrographs would be used as input at all inflow points for the unsteady state flow modeling.

\section{Sediment Sampling}

Five suspended sediment samples were collected in plastic 1 liter bottles at each inflow and outflow point and below the dam. The number of samples was limited by project costs but it is believed that enough samples were collected to determine the changes in sediment inflow. One bed material sample was collected at the sampling points by scooping materials from the bed at two or three locations along the discharge range. The wash load samples are tabulated in Table 18. Table 19 is a summary of collected data for all gage locations. 
TABLE 10. Water Surface Stages, Conno isarauley Creek

Location: Gage at left bank tied to bridge Wingwall about 0.4 miles upstream of Cattaraugas Creek

Datum: Top of gage $=100.0 \mathrm{ft}$. (arbitrary)

\begin{tabular}{|c|c|c|c|}
\hline Date & Time & Stage & Remarks \\
\hline $4 / 26 / 79$ & $\begin{array}{l}0745 \\
1102 \\
1438 \\
2020 \\
2203 \\
2325\end{array}$ & $\begin{array}{l}96.92 \\
96.92 \\
96.92 \\
96.92 \\
96.92 \\
96.92\end{array}$ & $\begin{array}{l}\text { Light rain } \\
\text { Light rain } \\
\text { Light rain }\end{array}$ \\
\hline $4 / 27 / 79$ & $\begin{array}{l}0140 \\
0305 \\
0435 \\
0610 \\
0748 \\
0952 \\
1108 \\
1420 \\
1626 \\
1750 \\
2137 \\
2320\end{array}$ & $\begin{array}{l}96.92 \\
97.00 \\
96.96 \\
97.00 \\
97.04 \\
97.04 \\
97.13 \\
97.08 \\
97.08 \\
97.08 \\
97.04 \\
97.04\end{array}$ & Light rain \\
\hline $4 / 28 / 79$ & $\begin{array}{l}0141 \\
0335 \\
0506 \\
0745 \\
0930 \\
1110 \\
1440 \\
1750 \\
2150 \\
2310\end{array}$ & $\begin{array}{l}97.00 \\
97.00 \\
97.00 \\
97.00 \\
97.00 \\
97.00 \\
97.00 \\
96.96 \\
96.96 \\
96.96\end{array}$ & Light rain \\
\hline $4 / 29 / 79$ & $\begin{array}{l}0100 \\
0245 \\
0444 \\
0655\end{array}$ & $\begin{array}{l}97.00 \\
97.00 \\
96.96 \\
96.96\end{array}$ & \\
\hline
\end{tabular}


TABLE 11. Water Surface Stages, Spooner Creek

Location: Gage at left bank under Zoar Valley Road Bridge 0.5 miles upstream of Cattaraugas Creek

Datum: Top of gage $=100.0 \mathrm{ft}$. (arbitrary)

\begin{tabular}{|c|c|c|c|}
\hline Date & Time & Stage & Remarks \\
\hline $4 / 26 / 79$ & $\begin{array}{l}0730 \\
1053 \\
1415 \\
2000 \\
2150 \\
2335\end{array}$ & $\begin{array}{l}97.21 \\
97.21 \\
97.21 \\
97.17 \\
97.17 \\
97.21\end{array}$ & $\begin{array}{l}\text { Wind } 5-10 \mathrm{mph} \text { (est.) } \\
\text { Wind } 0-5 \mathrm{mph} \text { (est.) } \\
\text { Wind } 5-10 \mathrm{mph} \text { (est.) } \\
\text { Light rain } \\
\text { Light rain } \\
\text { Light rain }\end{array}$ \\
\hline
\end{tabular}

$4 / 27 / 79 \quad 0125 \quad 97.21$

$0255 \quad 97.21 \quad$ Light rain

$0440 \quad 97.21 \quad$ Light rain

$0620 \quad 97.25$

$0755 \quad 97.29$

$0940 \quad 97.29$

$1056 \quad 97.25$

$1400 \quad 97.29$

161597.25

$1740 \quad 97.25$

$2120 \quad 97.25$

$2300 \quad 97.29$

$4 / 28 / 79 \quad 0100 \quad 97.33$

$0320 \quad 97.29$

$0455 \quad 97.29$

$0730 \quad 97.25$

$0915 \quad 97.25$

$1105 \quad 97.25$

$1330 \quad 97.25$

$1730 \quad 97.21$

$2145 \quad 97.21$

$2250 \quad 97.25$

Light rain

$4 / 29 / 79 \quad 0050 \quad 97.29$

$0230 \quad 97.29$

$0430 \quad 97.29$

$0646 \quad 97.25$ 
TABLE 12. Water Surface Stages, Spring Brook

Location: Gage at center of channel about $1000 \mathrm{ft}$ upstream of Cattaraugas Creek

Datum: Top of gage $=100.0 \mathrm{ft}$. (arbitrary)

\begin{tabular}{cccc} 
Date & Time & Stage & Remarks \\
\cline { 2 - 3 } $4 / 26 / 79$ & 0833 & 97.67 & \\
& 1142 & 97.67 & \\
& 1525 & 97.67 & \\
& 2100 & 97.62 & Light rain \\
$4 / 27 / 79$ & 2240 & 97.62 & Light rain \\
& 0055 & 97.62 & \\
& 0215 & 97.67 & \\
& 0355 & 97.62 & Light rain \\
& 0520 & 97.67 & Light rain \\
& 0655 & 97.71 & Light rain \\
& 0820 & 97.71 & \\
& 1028 & 97.71 & \\
& 1215 & 97.75 & \\
& 1515 & 97.75 & \\
& 1704 & 97.71 & \\
& 2050 & 97.71 & \\
& 2215 & 97.71 & \\
& 2359 & 97.71 & \\
$4 / 28 / 79$ & 0230 & 97.67 & \\
& 0425 & 97.67 & \\
& 0540 & 97.67 & \\
& 0815 & 97.67 & \\
& 1003 & 97.67 & \\
& 1145 & 97.67 & \\
& 1410 & 97.61 & \\
& 1830 & 96.67 & Light rain \\
& 2225 & 96.67 & \\
& 2340 & 97.61 & \\
& & \\
$4 / 29 / 79$ & 0135 & 97.67 & \\
& 0325 & 97.61 & \\
& 0515 & 97.67 & \\
& 0730 & 96.57 &
\end{tabular}


TABLE 13. Water Surface Stages, Franks Creek

Location: Gage at left wall of railroad culvert barrel about $150 \mathrm{ft}$ upstream of Buttermilk Creek at sampling station $\mathrm{FC}-1$.

Datum: Top of gage $=100.0 \mathrm{ft}$. (arbitrary)

\begin{tabular}{llll} 
Date & Time & Stage & \multicolumn{1}{c}{ Remarks } \\
\cline { 3 - 4 } $4 / 26 / 79$ & 0940 & 97.33 & wind 5-10 mph (est.) \\
& 1035 & 97.33 & \\
1135 & 97.33 & \\
1230 & 97.33 & \\
1330 & 97.33 & \\
1430 & 97.33 & \\
1500 & 97.33 & \\
1730 & 97.33 & \\
1830 & 97.33 & \\
1930 & 97.33 & \\
2030 & 97.33 & Light rain \\
& 2130 & 97.37 & Heavy rain \\
& 2230 & 97.33 & \\
& 2330 & 97.37 & Rain stopped \\
& & \\
0030 & 97.33 & \\
1030 & 97.33 & \\
0230 & 97.37 & \\
0330 & 97.33 & \\
0350 & 97.33 & Light rain \\
0410 & 97.33 & Rain stopped \\
0430 & 97.33 & Light rain \\
0500 & 97.33 & Light rain \\
0530 & 97.37 & Light rain \\
0600 & 97.37 & Light rain \\
0630 & 97.42 & Steady rain increased \\
& & & sediment load \\
& 0945 & 97.46 & \\
1100 & 97.46 & \\
1200 & 97.50 & \\
1300 & 97.50 & \\
1400 & 97.50 & \\
1505 & 97.50 & \\
1605 & 97.50 & \\
1707 & 97.50 & \\
1800 & 97.50 & \\
1900 & 97.46 & \\
1953 & 97.45 & \\
& & &
\end{tabular}


TABLE 13. Continued

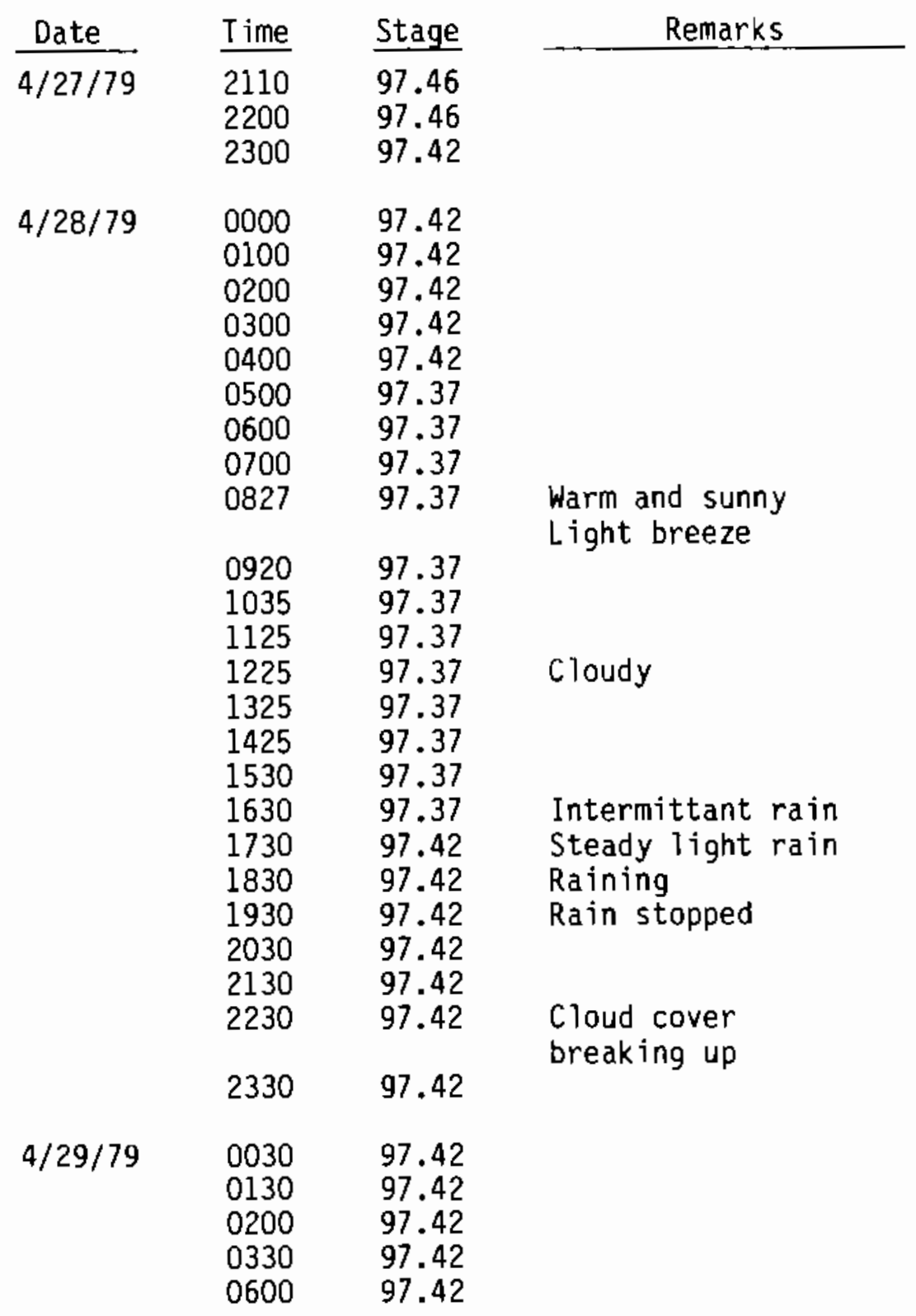


TABLE 14. Water Surface Stages, Buttermilk Creek

Location: Gage at left bank about $150 \mathrm{ft}$ upstream of Franks Creek and about 12,500 ft upstream of Cattaraugas Creek at station BC-1A.

Datum: Top of gage $=100.0 \mathrm{ft}$. (arbitrary)

\begin{tabular}{|c|c|c|c|}
\hline Date & Time & Stage & Remarks \\
\hline $4 / 26 / 79$ & $\begin{array}{l}0930 \\
1030 \\
1100 \\
1140 \\
1205 \\
1230 \\
1300 \\
1330 \\
1400 \\
1430 \\
1500 \\
1530 \\
1600 \\
1730 \\
1830 \\
1930 \\
2030 \\
2130 \\
2230 \\
2330\end{array}$ & $\begin{array}{l}95.71 \\
95.71 \\
95.71 \\
95.71 \\
95.71 \\
95.71 \\
95.71 \\
95.71 \\
95.71 \\
95.71 \\
95.71 \\
95.71 \\
95.71 \\
95.71 \\
95.71 \\
95.71 \\
95.71 \\
95.71 \\
95.71 \\
95.71\end{array}$ & $\begin{array}{l}\text { Light rain } \\
\text { Intermittent rain } \\
\text { Heavy rain } \\
\text { Rain stopped }\end{array}$ \\
\hline
\end{tabular}

$4 / 27 / 79 \quad 0030 \quad 95.71$

$0130 \quad 95.71$

$0230 \quad 95.71$

$0330 \quad 95.71$

0350 no reading light rain

0410 no reading Rain stopped

$0430 \quad 95.75$ Light rain

$0500 \quad 95.75 \quad$ Light rain

$0530 \quad 95.75$ Light rain

$0600 \quad 95.75 \quad$ Light rain

$0630 \quad 95.75$ very iight rain

$0945 \quad 95.92 \quad$ Steady rain increased

sediment load

$\begin{array}{rrr} & 1100 & 95.92 \\ & 1200 & 96.00 \\ & 1300 & 96.00 \\ & 1400 & 96.04 \\ 4 / 27 / 79 & 1505 & 96.04 \\ & 1600 & 96.04 \\ & 1705 & 96.00\end{array}$


TABLE 14. Continued

\begin{tabular}{|c|c|c|c|}
\hline Date & Iime & Stage & Remarks \\
\hline & $\begin{array}{l}1730 \\
1737 \\
1739 \\
1741 \\
1745 \\
1758 \\
1815 \\
1830 \\
1855 \\
1917 \\
1934 \\
1955 \\
2020 \\
2110 \\
2130 \\
2200 \\
2300\end{array}$ & $\begin{array}{l}96.42 \\
96.50 \\
96.54 \\
96.58 \\
96.58 \\
96.50 \\
96.54 \\
96.54 \\
96.54 \\
96.54 \\
96.54 \\
96.04 \\
95.96 \\
95.87 \\
95.87 \\
95.87 \\
95.87\end{array}$ & \\
\hline $4 / 28 / 79$ & $\begin{array}{l}0000 \\
0100 \\
0200 \\
0300 \\
0400 \\
0500 \\
0600 \\
0700 \\
0830 \\
0925 \\
1030 \\
1128 \\
1230 \\
1330 \\
1430 \\
1540 \\
1630 \\
1730 \\
1830 \\
1930 \\
2030 \\
2130 \\
2230 \\
2330\end{array}$ & $\begin{array}{l}95.83 \\
95.83 \\
95.79 \\
95.79 \\
95.79 \\
95.79 \\
95.79 \\
95.79 \\
95.79 \\
95.79 \\
95.79 \\
95.79 \\
95.79 \\
95.79 \\
95.79 \\
95.79 \\
95.79 \\
95.79 \\
95.79 \\
95.79 \\
95.79 \\
95.79 \\
95.79 \\
95.79\end{array}$ & $\begin{array}{l} \\
\text { Cloudy } \\
\text { Intermittent rain } \\
\text { Steady light rain } \\
\text { Rain continuing } \\
\text { Rain stopped } \\
\text { Cloud cover breaking up }\end{array}$ \\
\hline $4 / 29 / 79$ & $\begin{array}{l}0030 \\
0130 \\
0200 \\
0330 \\
0602\end{array}$ & $\begin{array}{l}95.79 \\
95.79 \\
95.79 \\
95.79 \\
95.79\end{array}$ & \\
\hline
\end{tabular}


TABLE 15. Water Surface Stages, Cattaraugas Creek at Scobey Bridge

Location: Gage at right bank about $500 \mathrm{ft}$ downstream of Scobey Hili Road Bridge 36.15 miles upstream of Lake Erie

\begin{tabular}{|c|c|c|c|}
\hline Date & Time & Stage & Remarks \\
\hline $4 / 26 / 79$ & $\begin{array}{l}0812 \\
1126 \\
1510 \\
2045 \\
2225\end{array}$ & $\begin{array}{l}94.83 \\
94.83 \\
94.83 \\
94.83 \\
94.83\end{array}$ & \\
\hline $4 / 27 / 79$ & $\begin{array}{l}0020 \\
0155 \\
0320 \\
0505 \\
0635 \\
0816 \\
1014 \\
1201 \\
1500 \\
1645 \\
2150 \\
2325\end{array}$ & $\begin{array}{l}94.83 \\
94.83 \\
94.83 \\
94.87 \\
94.87 \\
94.92 \\
94.96 \\
95.04 \\
95.21 \\
95.17 \\
95.21 \\
95.17\end{array}$ & $\begin{array}{l}\text { Light rain } \\
\text { Light rain } \\
\text { Raining }\end{array}$ \\
\hline $4 / 28 / 79$ & $\begin{array}{l}0215 \\
0415 \\
0530 \\
0755 \\
0945 \\
1130 \\
1335 \\
1815 \\
2205 \\
2320\end{array}$ & $\begin{array}{l}95.17 \\
94.17 \\
95.17 \\
95.12 \\
95.12 \\
95.08 \\
95.04 \\
95.00 \\
94.96 \\
94.92\end{array}$ & Light rain \\
\hline $4 / 29 / 79$ & $\begin{array}{l}0125 \\
0310 \\
0506 \\
0715\end{array}$ & $\begin{array}{l}94.96 \\
94.92 \\
94.96 \\
94.96\end{array}$ & \\
\hline
\end{tabular}


TABLE 16. Water Surface Stages. Springville Dam - Cattaraugas Creek

Location: Gage attached to steel ladder in forebay of power plant 36.4 miles upstream of Lake Erie near sampling station $\mathrm{CC}-5$.

Datum: Top of gage $=0.0 \mathrm{ft}$. (level with spillway crest)

\begin{tabular}{cccc} 
Date & Time & Stage & Remarks \\
\hline $4 / 26 / 69$ & 0800 & 0.25 & \\
& 1117 & 0.25 & \\
& 1456 & 0.25 & \\
& 2040 & 0.25 & Light rain \\
$4 / 27 / 79$ & 2218 & 0.25 & Light rain \\
& 0035 & 0.25 & Light rain \\
& 0330 & 0.21 & Light rain \\
& 0515 & 0.25 & Light rain \\
& 0640 & 0.33 & \\
& 0822 & 0.38 & \\
& 1005 & 0.29 & \\
& 1153 & 0.38 & \\
& 1445 & 0.50 & \\
& 1655 & 0.50 & \\
& 1845 & 0.50 & \\
& 2200 & 0.54 & \\
& 2335 & 0.50 & \\
$4 / 28 / 79$ & 0155 & 0.58 & \\
& 0405 & 0.58 & \\
& 0525 & 0.54 & \\
& 0805 & 0.42 & \\
& 0905 & 0.42 & \\
& 1133 & 0.42 & \\
& 1402 & 0.42 & \\
& 1800 & 0.33 & Light rain \\
& 2215 & 0.38 & \\
& 2325 & 0.33 & \\
& & \\
& 0120 & 0.33 & \\
& 0300 & 0.33 & \\
& 0459 & 0.33 & \\
& 0715 & 0.21 & \\
& & &
\end{tabular}


IABLE 17. Water Surface Stages, Cattaraugas Creek at Bigelow Bridge

Location: Gage at right bank under bridge 41.3 miles upstream of Lake Erie at sampling station CC-1.

Datum: Top of gage $=100.0 \mathrm{ft}$. (arbitrary)

\begin{tabular}{|c|c|c|c|}
\hline Date & Time & Stage & Remarks \\
\hline $4 / 26 / 69$ & $\begin{array}{l}0845 \\
1150 \\
1538 \\
2125 \\
2252\end{array}$ & $\begin{array}{l}95.79 \\
95.79 \\
95.79 \\
95.79 \\
95.79\end{array}$ & $\begin{array}{l}\text { Light rain } \\
\text { Light rain }\end{array}$ \\
\hline
\end{tabular}

$4 / 27 / 79 \quad 0105 \quad 95.79$

$0225 \quad 95.79$

$0405 \quad 95.83$ Light rain

$0530 \quad 95.83$ Light rain

$0700 \quad 95.83$ Light rain

$\begin{array}{lll}0835 & 95.87 & \text { Light rain } \\ 1040 & 95.92 & \text { Light rain }\end{array}$

$1223 \quad 95.96$

$1530 \quad 96.04$

$1710 \quad 96.04$

$2100 \quad 96.08$

$2227 \quad 96.12$

$4 / 28 / 79 \quad 0015 \quad 96.12$

$0250 \quad 96.08$

$0437 \quad 96.04$

$0550 \quad 96.04$

$0825 \quad 96.00$

$1010 \quad 96.00$

$1200 \quad 95.96$

$1420 \quad 96.96$

$1845 \quad 95.87$

$2235 \quad 95.92$

$2250 \quad 95.92$

$4 / 29 / 79 \quad 0200 \quad 95.96$

$0335 \quad 95.87$

$0523 \quad 95.87$

$0740 \quad 95.87$ 
IABLE 18. Suspended Sediment Samples

\begin{tabular}{|c|c|c|c|c|c|}
\hline _.._Lcation & $\begin{array}{l}\text { Sample } \\
\text { No. }\end{array}$ & Date & Time & Stage & $\begin{array}{l}\text { Concentration } \\
(\mathrm{mg} / \mathrm{l})\end{array}$ \\
\hline \multirow[t]{5}{*}{ Franks Creek (FC-1) } & 1 & $4-26$ & 1635 & 97.33 & 60.0 \\
\hline & 2 & $4-27$ & 1100 & 97.46 & 238.0 \\
\hline & 3 & $4-28$ & 0920 & 97.37 & 88.3 \\
\hline & 4 & $4-28$ & 1425 & 97.37 & 84.0 \\
\hline & 5 & $4-29$ & 0556 & 97.42 & 128.2 \\
\hline \multirow[t]{5}{*}{ Buttermilk Creek $(B C-1 A)$} & 1 & $4-26$ & 1637 & 95.71 & 3.7 \\
\hline & 2 & $4-27$ & 1100 & 95.92 & 31.4 \\
\hline & 3 & $4-28$ & 0925 & 95.79 & 8.3 \\
\hline & 4 & $4-28$ & 1430 & 95.79 & 1.4 \\
\hline & 5 & $4-29$ & 0559 & 95.79 & 8.4 \\
\hline Cattaraugas Creek at & 1 & $4-26$ & 1538 & 95.79 & 4.05 \\
\hline \multirow[t]{4}{*}{ Bige iow Bridge $(C C-1)$} & 2 & $4-27$ & 1530 & 76.04 & 28.0 \\
\hline & 3 & $4-28$ & $\mathrm{D} 250$ & 96.08 & 49.8 \\
\hline & 4 & $4-28$ & 1845 & 95.87 & 27.2 \\
\hline & 5 & $4-29$ & 0035 & 95.87 & 3.8 \\
\hline Cataraugas Creek at & 1 & $4-26$ & 1510 & 94.83 & 13.7 \\
\hline \multirow[t]{4}{*}{ Scobey 8ridge } & 2 & $4-27$ & 1500 & 95.31 & 37.9 \\
\hline & 3 & $4-28$ & 0215 & 95.17 & 39.6 \\
\hline & 4 & $4-28$ & 1815 & 95.00 & 15.6 \\
\hline & 5 & $4-29$ & 0310 & 94.92 & 4.4 \\
\hline Cattaraugas Creek at & 1 & $4-26$ & 1428 & 94.83 & 3.2 \\
\hline \multirow[t]{4}{*}{ Frye 8ridge } & 2 & $4-27$ & 1410 & 95.04 & 17.6 \\
\hline & 3 & $4-28$ & 0135 & 95.17 & 44.8 \\
\hline & 4 & $4-28$ & 1745 & 94.96 & 24.3 \\
\hline & 5 & $4-29$ & 0240 & 94.92 & 4.2 \\
\hline
\end{tabular}


TABLE 18. Continued

\begin{tabular}{|c|c|c|c|c|c|}
\hline Location & $\begin{array}{l}\text { Sample } \\
\text { No. }\end{array}$ & Date & Time & Stage & $\begin{array}{l}\text { Concentration } \\
(m g / l)\end{array}$ \\
\hline \multirow[t]{5}{*}{ Spring Brook } & 1 & $4-26$ & 1525 & 94.67 & 127.2 \\
\hline & 2 & $4-27$ & 1515 & 97.75 & 199.8 \\
\hline & 3 & $4-28$ & 0230 & 97.67 & 212.1 \\
\hline & 4 & $4-28$ & 1820 & 97.67 & 191.8 \\
\hline & 5 & $4-29$ & 0325 & 97.61 & 132.4 \\
\hline \multirow[t]{5}{*}{ Spooner Creek } & 1 & $4-26$ & 1415 & 97.21 & 28.2 \\
\hline & 2 & $4-27$ & 1400 & 97.29 & 11.4 \\
\hline & 3 & $4-28$ & 0100 & 97.33 & 31.4 \\
\hline & 4 & $4-28$ & 1730 & 97.21 & 5.2 \\
\hline & 5 & $4-29$ & 0230 & 97.29 & (a) \\
\hline
\end{tabular}

(a) sample container damaged in shipment 
TABLE 19. Data Summary

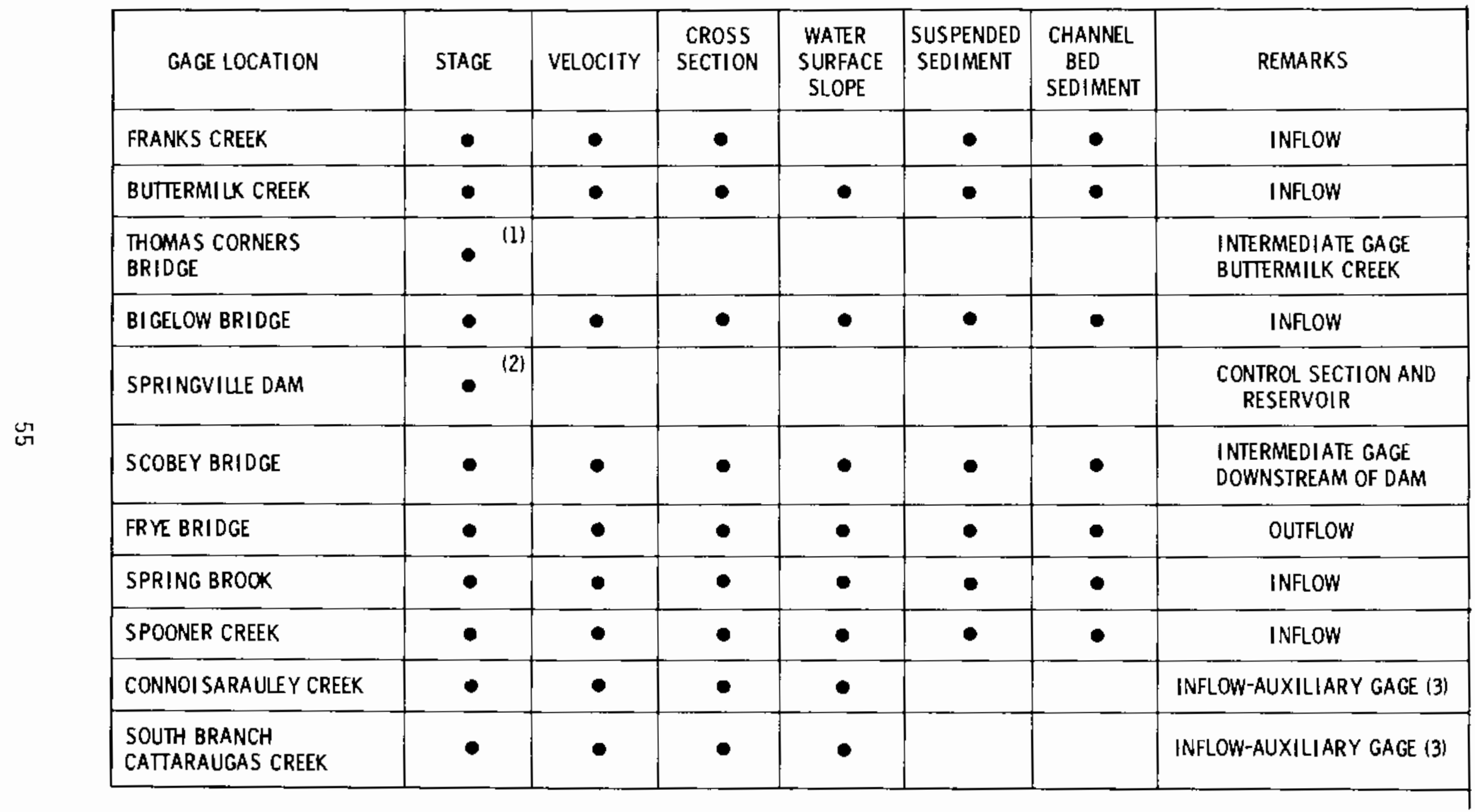

1. NEW YORK STATE GEOLOGICAL SURVEY AUTOMATIC STAGE RECORDER.

2. DEPTH OF FLOW OVER SPILLWAY.

3. AUXILIARY GAGES TO MONITOR FLOW FROM TYPICAL LARGE TRIBUTARY BASINS. 



\section{REFERENCES}

Dana, R. H. et a1. 1979. "General Investigation of Radionuclide Retention in Migration Pathways at the West Valley, New York Low-Level Burial Site Annual Report September 1, 1977-September 30, 1978," New York State Geological Survey. Prepared for U.S. Nuclear Regulatory Comission, Washington, D.C., NUREG/CR-0794.*

Ecker, R. M. and Y. Onishi. 1979. "Sediment and Radionuclide Transport in Rivers, Phase 1: Field Sampling Program Ouring Mean Flow Cattaraugus and Buttermi 1k Creeks, New York," PNL-2551. Prepared for U.S. Nuclear Regulatory Cormission, Washington, D.C., NUREG/CR-0576.**

\footnotetext{
*Available for purchase from the NRC/GPO Sales Program, U.S. Nuclear Regulatory Commission, Washington, DC 20555, and the National Technical Information Service, Springfield, VA 22161.

**Available for purchase from the National Technical Information Service, Springfield, VA 22161.
} 



\section{DISTRIBUTION}

No. of

Copies

A. A. Churm

DOE Patent Division

9800 South Cass Avenue

Argonne, IL 60439

411 U.S. Nuclear Regulatory Commission

Division of Technical Information and Document Control

7920 Norfolk Avenue

Bethesda, MD 20014

2 DOE Technical Information Center

Phillip R. Reed

U.S. Nuclear Regulatory

Commission

Office of Nuclear Regulatory Research

Heaith and Environmental

Research Branch

Washington, OC 20555

Paul Lohaus

U.S. Nuclear Regulatory Commission

Low Level Waste Branch

Office of Nuclear Materials

Safety and Safeguards

Washington, DC 20555

3 Dr. Robert H. Fakundiny

New York State Geological Survey

The State Education Department

Albany, NY 12234

J. P. Duckworth

Genera I Manager

Nuclear Fuel Services, Inc.

P.0. Box 124

West Valley, NY 14171
No. of

Copies

William Schell

University of Washington

College of Fisheries

Seattle, WA 98195

James Thomas

U.S. Nuclear Regulatory

Commission

Low Level Waste Branch

Office of Nuclear Materials

Safety \& Safeguards

Washington, DC 20555

Peter Van Voris

Battelle Columbus Laboratories

$505 \mathrm{King}$ Avenue

Columbus, $\mathrm{OH} 43201$

R. M. Ecker

Towill, Inc.

$221 \mathrm{E}$. Columbia Dr.

Kennewick, WA 99336

ONSITE

50 Pacif ic Northwest Laboratory

S. M. Brown

D. B. Cearluck

D. W. Dawson

Y. Onishi (24)

R. J. Serne

W. H. Walters (10)

Technical Information (5)

Publishing Coordination (BE)

Water and Land Resources 

NRC FOAM $35 \%$ $(7.77)$
U.8. NUCLEAR REOULATOAY COMMISSION BIBLIOGRAPHIC DATA SHEET
1. REPORT NUMBER (A ssigned by DDC)

NUREG/CR -1387

PNL -3329

2. (Leove biank)

3. RECIPIENT'S ACCESSION NO.

5. DATE REPORT COMPLETED \begin{tabular}{l|l}
\hline MONTH & YEAR \\
\hline SEPTEMbER
\end{tabular} September 1980

9. PERFORMING ORGANIZATION NAME AND MAILING ADDRESS (Inglude Zip Code)

Pacific Northwest Laboratory Richland, WA 99352

12. SPONSORING ORGANIZATION NAME AND MAILING ADDRESS (inciude $Z i p$ Code)

Division of Safeguards, Fuel Cycle and

Environmental Research

Office of Nuclear Regulatory Research

U.S. Nuclear Regulatory Commission

Washington, DC. 20555

13. TYPE OF REPORT

\section{ABSTRACT (200wards or less)}

This report describes FY-1979 analysis results on flow, sediment and radionuclide data collected in Cattaraugus, Buttermilk and Franks Creek, New York. The objective of this study is to investigate the radionuclide transport in these streams as part of a continuing program to provide data required for application and verification of the Sediment and Radionuclide Transport Model (SERATRA). Radiological analyses were performed on sand, silt and clay size fractions of suspended and bed sediment, as well as for dissolved radionuclides.

\begin{tabular}{|l|l|}
\hline $\begin{array}{l}\text { 19. SECURITY CLASS (This roport) } \\
\text { Unclassified }\end{array}$ & 21. NO. OF PAGES \\
\hline $\begin{array}{l}\text { 20. SECURITY ÇLASS (This onge) } \\
\text { Unclass iftied }\end{array}$ & $\begin{array}{c}\text { 22. PRICE } \\
\text { S }\end{array}$ \\
\hline
\end{tabular}


